\title{
ANALISIS KEHILANGAN FISIK DAN TINGKAT KEPUASAN PELANGGAN PADA DMA UNIT 3 ILIR PDAM TIRTA MUSI PALEMBANG
}

\author{
RENI ANDAYANI ${ }^{1)}$, ANI FIRDA ${ }^{2)}$, ROSMALINDA PERMATASARI ${ }^{3)}$ \\ Jurusan Teknik Sipil, Fakultas Teknik, Universitas Tridinanti Palembang \\ Jalan Dharmapala No.1A Bukit Besar Palembang 30139 \\ e-mail : re_an3@yahoo.com ${ }^{1)}$, anifirda@univ-tridinanti.ac.id ${ }^{2)}$,rosmalinda_mt@yahoo.com ${ }^{3)}$
}

\begin{abstract}
ABSTRAK
Kebutuhan air bersih masyarakat semakin hari semakin meningkat, sedangkan kapasitas produksi sumber air bersih relatif menurun, hal yang relevan untuk dilakukan adalah meminimalkan tingkat kehilangan air dengan program pengendalian Non Revenued Water (NRW). Salah satu usaha Perusahaan Daerah Air Minum (PDAM) untuk menekan angka NRW adalah dengan membentuk suatu wilayah pengaliran (jaringan distribus)i dan menempatkan meter induk sebagai sistem pengontrolan, yang dinamakan Distric Metered Area (DMA). Untuk mengetahui efektifitas setelah pemasangan DMA Unit 3 Ilir PDAM Tirta Musi ini dilakukan analisis Infrastructure Leakage Index (ILI). Hasil penelitian didapatkan nilai ILI pada setelah pemasangan DMA Unit 3 Ilir PDAM sebesar 10.98. Nilai tersebut termasuk dalam kategori kelas $C$, dimana indikatornya adalah pencatatan kebocoran yang buruk; hanya dapat ditoleransi bila airnya berlimpah dan murah; meskipun begitu, harus tetap dianalisis tingkat dan penyebab kebocoran dan intensifkan upaya penurunan kebocoran. Skala tingkat kepuasan pelanggan terhadap pelayanan setelah pemasangan DMA unit 3 Ilir senilai 4.05, artinya pelanggan merasa puas dengan air yang dikonsumsi dari PDAM Tirta Musi Unit 3 Ilir Palembang.
\end{abstract}

Keywords : NRW, ILI, DMA, dan PDAM Tirta Musi.

\section{LATAR BELAKANG}

Air bersih merupakan salah satu kebutuhan dasar yang dibutuhkan untuk kelangsungan hidup umat manusia, namun ketersediaan air bersih semakin hari semakin berkurang. Hal ini disebabkan oleh pesatnya peningkatan pertumbuhan penduduk dan eksplorasi air tanah yang berlebihan. Untuk memberikan pelayanan penyediaan air bersih, peningkatan kemampuan khususnya kemampuan distribusi merupakan usaha yang harus terus dilakukan. Dalam meningkatkan kemampuan tersebut pemeliharaan pada jaringan distribusi dan transmisi perlu menjadi perhatian.

Air tak berekening dapat dinyatakan dengan istilah NRW (Non Revenue Water). Secara keseluruhan tingkat kehilangan air di PDAM Tirta Musi Palembang sebesar 27,82\% (PDAM Tirta Musi, 2016), sedangkan pada unit 3 ilir sebesar 34\%. Angka ini masih melebihi ketentuan dibandingkan dengan standar nasional yaitu antara $20-25 \%$, salah satu penyebab tingginya NRW dikarenakan banyak terdapat kebocoran pipa. Oleh karena itu diperlukan suatu sistem yang dapat mengurangi tingkat kebocoran tersebut.

Salah satu sistem dengan alat pengontrol kebocoran jaringan air bersih adalah DMA (District Meter Area), yaitu suatu cara yang dapat mendeteksi kebocoran yang tidak tampak, dengan membentuk suatu wilayah pengaliran dengan menempatkan meter induk di setiap wilayah pengaliran. Pengukuran kinerja DMA digunakan Indikator Kehilangan Fisik atau Infrastructure Leakage Index (ILI), sehingga dapat diketahui bagaimana kinerja jaringan pada DMA serta langkah yang harus dilakukan untuk peningkatan kinerja.

Pada penelitian ini digunakan DMA unit 3 Ilir, yang meliputi wilayah Boom Baru, Veteran 1, Penyaringan, Veteran 2, Kebon Jahe, Mangkubumi, Bambang Utoyo, Sungai Batang, Taman Kenten, Duku Kanan, dan Sekip Bendung. Jumlah total pelanggan sampai 
dengan bulan Februari 2016 sebanyak 32.437 sambungan langganan (SL). Sebagai pembanding, dilakukan juga analisa tingkat kepuasan pelanggan setelah pemasangan DMA melalui wawancara dengan menggunakan kuesioner yang kemudian diolah dengan analisis statistik.

\section{LANDASAN TEORI Definisi Kehilangan Air}

Kehilangan air merupakan selisih antara jumlah air yang masuk ke dalam jaringan dengan jumlah air yang dikonsumsi secara resmi oleh konsumen. Konsumsi resmi merupakan volume air tahunan yang bermeter maupun tidak bermeter, yang dikonsumsi atau diambil oleh pelanggan yang sudah terdaftar secara resmi, supplier air dan pihak-pihak lain yang diperbolehkan.

\section{Pengertian NRW}

Non-revenued water (NRW) adalah perbedaan antara jumlah air yang diproduksi dengan air yang terjual atau yang didistribusikan kepada pelanggan melalui meter air. NRW dapat dipakai untuk memperkirakan jumlah total produksi air yang dapat digunakan (non-revenue producing water). Air yang hilang (lost water) adalah air yang terdistribusi dalam bentuk kebocoran (leaks) dan penggunaan lainya secara ilegal. Tingkat kehilangan air (\%NRW)

$$
=\frac{\text { Kehilangan Air }}{\text { Jumlah Air yang dipasok }} \times 100 \%
$$

\section{ILI (Infrastructure Leakage Index)}

ILI (Infrastructure Leakage Index) merupakan suatu angka untuk menilai kinerja yaitu kualitas pengelolaan jaringan distribusi (pemeliharaan, perbaikan, dan penggantian).

$$
\text { ILI } \quad=\frac{C A P L}{M A A P L}
$$

Dimana :

$$
\text { CAPL : Current (real) Annual Physical }
$$$$
\text { (Volume tahunan kehilangan fisik }
$$
saat ini)

MAAPL : Minimum Achievable Annual Physical Losses

(Kehilangan fisik minimum yang dapat dicapai)

$$
\begin{aligned}
& \text { Menghitung Indeks Kehilangan } \\
& \begin{array}{l}
\text { Infrastruktur ILI } \\
\text { Bocor = Input sistem } \quad-\quad \text { Pemakaian }
\end{array} \\
& \text { pelanggan } \\
& \text { CAPL }=(\text { Bocor }-4 / 100 \times \text { Pemakaian } \\
& \text { Pelanggan) /Jumlah Hari .......(2.3) } \\
& \text { MAAPL }=(18 \times \text { Panjang pipa } / 1000+0,8 x \\
& \text { Jumlah Sambungan) x (Tekanan } \\
& \text { rata-rata / } 1000
\end{aligned}
$$

\begin{tabular}{|c|c|c|c|c|c|c|c|}
\hline \multirow[t]{2}{*}{ Kat gort } & \multirow{2}{*}{$\begin{array}{l}\text { Kencris } \\
\text { Telenis }\end{array}$} & \multirow{2}{*}{ II } & \multicolumn{5}{|c|}{ 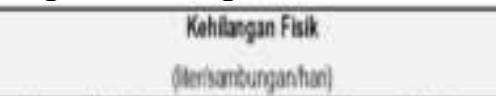 } \\
\hline & & & $10 \mathrm{~m}$ & $21 \mathrm{~mm}$ & $30 \mathrm{~m}$ & $40 \mathrm{n}$ & $50 \mathrm{~m}$ \\
\hline \multirow{4}{*}{$\frac{1}{2}$} & A & 1.2 & & 450 & $2 / 5$ & 4100 & 4125 \\
\hline & $B$ & 2.4 & & $50-100$ & $75-150$ & 100.2000 & $125-200$ \\
\hline & $c$ & 4.8 & & 100.200 & 150.300 & 200.400 & $200-500$ \\
\hline & 0 & 38 & & $>200$ & $>300$ & $>400$ & $>500$ \\
\hline \multirow{4}{*}{ 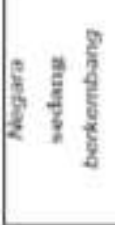 } & A & 1.4 & $<50$ & +180 & $<150$ & $<20$ & $<20$ \\
\hline & $B$ & $4-8$ & $50 \cdot 100$ & 100.200 & 150.300 & 200.400 & $280-500$ \\
\hline & $c$ & 8. 16 & 100.200 & 200.400 & 300.600 & 400.800 & $500-1000$ \\
\hline & 0 & $>16$ &, 200 & $\times 480$ & $>600$ & $>900$ & +100 \\
\hline
\end{tabular}

Bandingkan ILI dengan matriks target kehilangan fisik seperti yang terlihat pada tabel 1. berikut ini.

Tabel 1. Matriks Target Kehilangan Fisik

a) Kategori $\mathrm{A}$

Baik, Kebocoran sangat tidak signifikan sehingga bila dilakukan upaya penurunan kebocoran mungkin malah tidak ekonomis, kecuali dalam kasus terjadi kekurangan air baku. Perlu dilakukan analisis yang teliti untuk menemukan cara perbaikan yang paling cost effective.

b) Kategori B

Potensial, Ada potensi keberhasilan yang nyata. Kegiatan yang dapat dilakukan adalah pengaturan tekanan, pengendalian kebocoran aktif (ALC) yang lebih baik, serta perawatan jaringan yang lebih baik.

c) Kategori $\mathrm{C}$

Buruk, Kebocoran cukup parah, dapat ditoleransi hanya jika air melimpah dan murah. d) Kategori D

Kebocoran sangat parah, terjadi pemborosan sumber daya yang luar biasa. Program penurunan kebocoran menjadi keharusan dan harus diprioritaskan. 


\section{Distric Meter Area (DMA)}

District Meter Area (DMA) adalah salah satu alat deteksi kebocoran yang bersifat secara permanen berupa bagian daerah atau kawasan dari sistem jaringan distribusi yang dikhususkan menjadi daerah deteksi kebocoran pada program penurunan kehilangan air.

\section{Fungsi dan Sistem Kerja DMA}

Beberapa pendekatan dalam pemilihan dan penetapan DMA adalah bahwa DMA dipilih untuk tipe pemukiman domestik dan non domestik yang diprioritaskan untuk deteksi kebocoran. DMA ini merupakan bagian kecil dari daerah distribusi yang terdiri dari 500-2000 SL yang dapat dihitung. Dalam suatu DMA sebaiknya aliran air masuk berupa input tunggal, tetapi jika input yang masuk lebih dari satu tetap dapat digunakan dengan catatan seluruh input tersebut dapat diukur dengan tepat. DMA diharapkan memiliki kelengkapan peralatan pengukuran seperti meter induk, meter pelanggan, dan peralatan penunjang lainnya, juga harus mewakili dalam perhitungan untuk keseluruhan jaringan distribusi. Dengan adanya DMA ini diharapkan dapat membantu program penurunan NRW pada jaringan distribusi air minum.

\section{Menentukan Jumlah Sampel}

Sampel adalah bagian dari populasi yang digunakan untuk menyimpulkan atau menggambarkan populasi. Pemilihan sampel dengan metode yang tepat dapat menggambarkan kondisi populasi sesungguhnya yang akurat, dan dapat menghemat biaya penelitian secara efektif.

Salah satu metode yang digunakan untuk menentukan jumlah sampel dalam adalah menggunakan rumus Slovin (Sevilla et. Al., 2007) sebagai berikut :

$n=\frac{\mathrm{N}}{1+\mathrm{N} \cdot \mathrm{e}^{2}}$

Keterangan :

$\mathrm{n}=$ Jumlah Sampel

$\mathrm{N}=$ Jumlah Populasi

$\mathrm{e}=$ Batas Toleransi Kesalahan (ketentuan 5\%)

Rumus ini digunakan untuk menetapkan jumlah koresponden yang akan di analisa pada kurva permintaan. Untuk menggunakan rumus ini, pertama ditentukan berapa batas toleransi kesalahan. Batas toleransi kesalahan ini dinyatakan dengan persentase. Semakin kecil tolerasi kesalahan, semakin akurat sampel menggambarkan populasi. Misalnya, penelitian dengan batas kesalahan $15 \%$ berarti memiliki tingkat akurasi $85 \%$. Penelitian dengan kesalahan $2 \%$ memiliki tingkat akurasi sebesar 98\%.

\section{METODOLOGI PENELITIAN}

Bagan Alir Metodologi Penelitian ini dapat dilihat pada gambar dibawah ini :

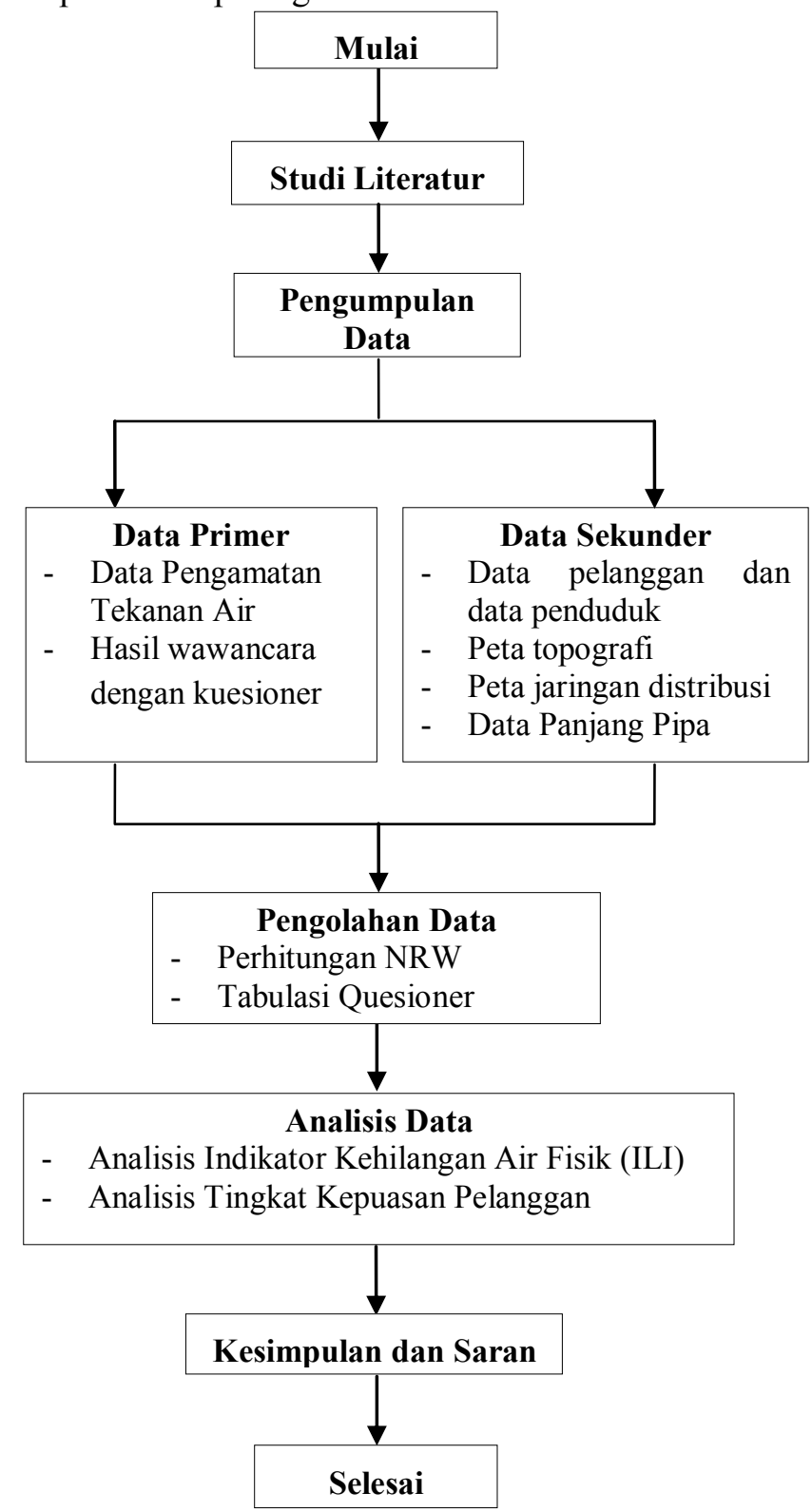

Gambar 1. Bagan Alir Metodologi Penelitian

\section{Lokasi Penelitian}

Lokasi penelitian ini berada pada DMA unit 3 Ilir, meliputi wilayah Boom Baru, Taman Kenten, Sekip Bendung, Kebon Jahe, Bambang Utoyo, Duku Kanan, Sungai Batang, Mangkubumi, Penyaringan, dan Veteran 1. 


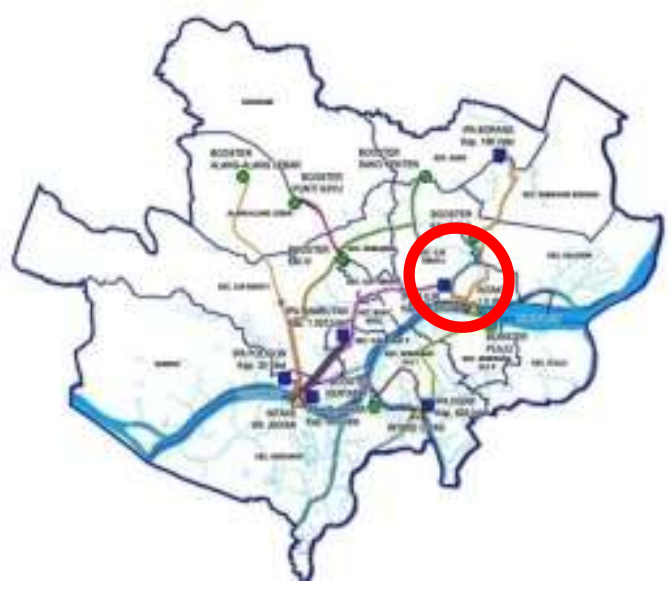

Gambar 2. Lokasi Penelitian

\section{Pengumpulan Data}

Metode pengumpulan data merupakan salah satu aspek yang berperan penting dalam kelancaran dan keberhasilan suatu penelitian. Pada penelitian ini menggunakan metode pengumpulan data kuantitatif, dan pengumpulan data berupa data primer dan data sekunder.

\section{Data Primer}

Data primer didapat dari pengamatan langsung data tekanan rata-rata pada manometer di tiap titik awal (node) di 10 (sepuluh) DMA, meliputi wilayah Boom Baru, Taman Kenten, Sekip Bendung, Kebon Jahe, Bambang Utoyo, Duku Kanan, Sungai Batang, Mangkubumi, Penyaringan dan Veteran 1.

Untuk analisis tingkat kepuasan pelanggan dilakukan wawancara langsung dengan menggunakan kuesioner. Kuesioner diambil pada salah satu wilayah DMA yang dianggap dapat mewakili yaitu DMA yang memiliki persentase ILI terendah.

\section{Data Sekunder}

Merupakan data-data penunjang data sekunder penelitian ini, berupa :

a. Peta jaringan pipa distribusi wilayah DMA 3 Ilir yang didapat dari PDAM Tirta Musi Palembang.

b. Peta topografi dari PDAM Tirta Musi.

c. Data panjang pipa

d. Mengumpulkan data pelanggan yang didapat dari PDAM Tirta Musi Palembang.

e. Data pemakaian air pelanggan perbulan yang diambil dari bulan Januari sampai Desember 2017.

\section{Analisa dan Perhitungan}

Data dikumpulkan dan dianalisa dengan metode deskriptif. Metode deskriptif merupakan suatu metode yang dilakukan dengan cara mengumpulkan data dari pencatatan lapangan, foto, dokumen, ataupun data-data yang dapat dijadikan petunjuk lainnya untuk digunakan dalam mencari data dengan interpretasi yang tepat. Metode ini digunakan untuk menggambarkan kondisi di lapangan, proses apa saja yang telah berlangsung dengan cara diagnosa dan menerangkan hubungan yang terjadi di lapangan dengan kajian teori, untuk kemudian dapat ditarik kesimpulan dari masalah yang ada, semuanya disusun secara sistemastis berdasarkan data-data yang telah dikumpulkan. Data yang terkumpul diolah dan disajikan dalam susunan yang baik dan rapi. Proses pengumpulan data dilakukan dengan tahapan pengolahan tabel dan dilanjutkan ke analisa data.

\section{Pengolahan Tabel dan Data}

Pengolahan tabel dan data meliputi tabulasi, penyajian data dalam bentuk grafik, dan perhitungan persentase menggunakan program Excel.

\section{Analisa Data}

Data yang sudah diolah kemudian akan dianalisa dan dihubungkan dengan indikator kinerja kehilangan air fisik melalui matriks target dan dapat ditarik kesimpulan dari keterangan kinerja teknis berdasarkan kelas yang didapat.

\section{ANALISA DATA}

Wilayah studi berada di District Meter Area (DMA) wilayah Unit 3 ilir PDAM Tirta Musi yaitu meliputi 10 (sepuluh) wilayah DMA yaitu DMA Boom Baru, DMA Taman Kenten, DMA Sekip Bendung, DMA Kebon Jahe, DMA Bambang Utoyo, DMA Duku Kanan, DMA Sungai Batang, DMA Mangkubumi, DMA Penyaringan, dan DMA Veteran 1. Total panjang pipa pada keseluruhan DMA adalah 133.271 meter.

Tabel 2. Rekapitulasi Panjang Pipa

DMA Unit 3 Ilir

\begin{tabular}{|c|c|c|}
\hline No & Lokasi DMA & $\begin{array}{c}\text { Total Panjang } \\
\text { Pipa (meter) }\end{array}$ \\
\hline 1 & Veteran 1 & 8594,8 \\
\hline 2 & Boom Baru & 8743,2 \\
\hline
\end{tabular}




\begin{tabular}{|c|c|c|}
\hline 3 & Penyaringan & 13131,6 \\
\hline 4 & Sekip Bendung & 20162 \\
\hline 5 & Kebon Jahe & 5624,3 \\
\hline 6 & Mangkubumi & 10114,6 \\
\hline 7 & Bambang Utoyo & 16666,4 \\
\hline 8 & Duku Kanan & 18253 \\
\hline 9 & Taman Kenten & 8449,1 \\
\hline 10 & Sungai Batang & 23532 \\
\hline \multicolumn{2}{|c|}{ Total } & 133271 \\
\hline
\end{tabular}

Sumber : PDAM Tirta Musi, 2018

Analisis ILI dimulai dengan perhitungan kehilangan/kebocoran fisik air atau Non Revenue Water (NRW), dan dilanjutkan dengan perhitungan CAPL dan MAAPL.

Salah satu faktor lain yang harus diketahui adalah tekanan yang diberikan pada setiap DMA dan panjang jaringan perpipaan total pada DMA.

Pencatatan tekanan dilakukan selama 24 jam pada manometer induk awal jaringan

\begin{tabular}{|c|c|c|c|c|c|c|c|c|c|}
\hline \multirow{2}{*}{ NO. } & \multirow{2}{*}{ NAMADMA } & \multirow{2}{*}{ JADWALPENGALRRN } & \multicolumn{6}{|c|}{ JAM PENGALIRAN } & \multirow{2}{*}{ SATUAN } \\
\hline & & & 00.005.D04.00 & O4.005.008.0 & $08.005 / d 12.00$ & $12.00 \mathrm{~s} / \mathrm{d} 16.00$ & $16,00 \mathrm{~s} / \mathrm{d} 20.00$ & $20.00 s . d 24.00$ & \\
\hline 1 & BOOMBARU & 00.00wibs.d 16.00wib & 1 & 1 & 0,2 & 0,8 & . & . & $\mathrm{atm}$ \\
\hline 2 & VETERAN1 & $\begin{array}{l}\text { O4. wibs.d 17.30 wib dan } \\
19.00 \text { wibs.d 22.00 wib }\end{array}$ & - & 0,8 & 1 & 0,2 & - & 0,2 & $\mathrm{~atm}$ \\
\hline 3 & PENYARINGAN & O4.00wibs.d21.00wib & . & 1,5 & 1,5 & 2,5 & 1,5 & . & $\mathrm{atm}$ \\
\hline 4 & VETERAN2 & $\begin{array}{l}\text { 04. wibs.d 17.30 wib dan } \\
\text { 19.00 wibs. L 22.00 wib }\end{array}$ & $\cdot$ & 0,8 & 1 & 0,2 & - & 0,2 & atm \\
\hline 5 & KEBON JAHE & 00.00wibs.d 16.00wib & . & 0,2 & 0,1 & 0,2 & - & . & $\mathrm{atm}$ \\
\hline 6 & MANGKUBUMI & 00.00wibs.d 16.00wib & 0,3 & 1,2 & 0,5 & 0,8 & - & . & $\mathrm{atm}$ \\
\hline 7 & BAMBANG UTOYO & 18.00wibs.d03.00wib & 0,8 & - & - & - & 0,8 & 1,5 & $\mathrm{~atm}$ \\
\hline 8 & SUNGA BATANG & 17.00wibs.d23.30 wib & . & . & . & . & 0,5 & 1,5 & $\mathrm{~atm}$ \\
\hline 9 & TAMAN KENTEN & 18.00wibs. 03.00wib & 0,8 & - & . & - & 0,8 & 1,5 & $\mathrm{~atm}$ \\
\hline 10 & DUKUKANAN & 17.00wibs.d 23.30 wib & . & . & - & . & 0,5 & 1,7 & $\mathrm{~atm}$ \\
\hline 11 & BENDUNG & $\begin{array}{l}\text { O4. wibs.d17.30 wib dan } \\
\text { 19.00wibs.d22.00 wib }\end{array}$ & - & 0,8 & 1 & 0,2 & - & 0,2 & $\mathrm{~atm}$ \\
\hline
\end{tabular}

DMA.

Perhitungan dilakukan pada setiap DMA, kemudian dilakukan rekapitulasi untuk mengetahui nilai ILI maksimal pada Unit 3 Ilir.

Tabel 3. Data Rata-rata Tekanan Manometer Per Hari DMA Unit 3 Ilir

Sumber : PDAM Tirta Musi, 2018

\section{DMA Boom Baru}

DMA Boom Baru digunakan sejak Desember 2010, jumlah pelanggan 1.083

Satuan Layanan dan pendistribusian air 53.223 m3/det. Tingkat kebocoran di DMA Boom Baru hingga Desember 2017 dapat ditekan sebesar 15,39\%. Berikut ini peta jaringan DMA Boom Baru:

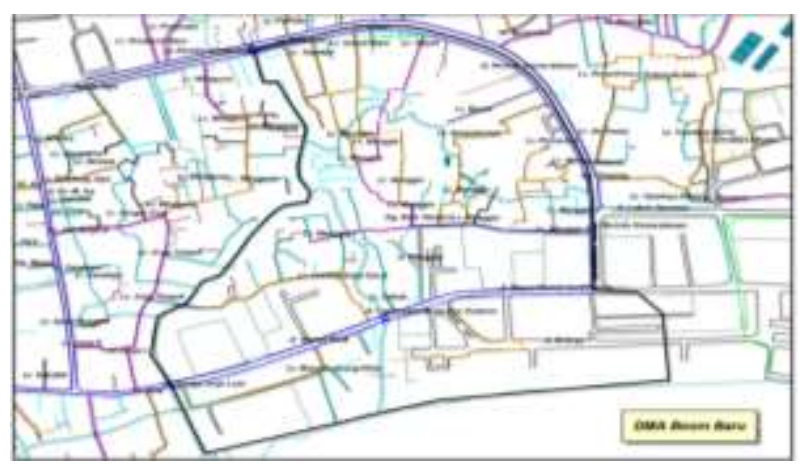

Gambar 2. DMA Boom Baru

(Sumber : PDAM Tirta Musi,2018)

Tabel 4. NRW dan ILI DMA Boom Baru

\begin{tabular}{|c|c|c|c|c|c|c|c|c|c|c|}
\hline $\sin$ & $\begin{array}{l}\text { Artat } \\
\text { Wart }\end{array}$ & $\begin{array}{l}\text { Jarise } \\
\text { Piarogn }\end{array}$ & $\sum_{p a s}^{k}$ & Terting & $\begin{array}{l}\text { NEN } \\
\text { nit) }\end{array}$ & $\begin{array}{l}\text { MFW } \\
\text { N }\end{array}$ & $\begin{array}{l}\text { Temen } \\
\text { tain } \\
\text { in }\end{array}$ & $\begin{array}{l}\text { cunt } \\
\mid \text { |niti }\end{array}$ & $\begin{array}{l}\text { wath } \\
\text { (ini) }\end{array}$ & U \\
\hline $\operatorname{man}$ & III & 194 & 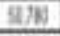 & (20111 & 10416 & 282 & $x$ & Difif & 0471 & $2 \mathrm{~T}$ \\
\hline Foton & $\frac{\pi}{2}$ & 604 & 59 & 4 (4) & D晋 & 11164 & $x$ & 10 & 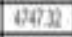 & $2 \%$ \\
\hline$\sqrt{15 n}$ & III & 10 & iㅐ & xi2 & $(10)$ & 116 & $x$ & (15) & क्यका & in \\
\hline 보료 & $x$ & 106 & 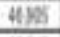 & 372 & 184) & 1186 & $x$ & 100 & 5ax & III \\
\hline in & 3I & 10 & $452 \mathrm{X}$ & 20154 & 128 & 1611 & $x$ & 780 & 4673 & 10 \\
\hline in & X & $12 \pi$ & Halls & xus? & 17 & 18.4 & $x$ & 773 & 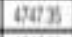 & 10 \\
\hline iu & $\pi$ & $10 \%$ & 4580 & 254 & 695 & 1018 & $x$ & 158 & 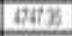 & 18 \\
\hline bats & $\pi$ & 106 & dibs & WEN & t48 & IiII) & $x$ & 100 & 40235 & 133 \\
\hline Bepriter & $x$ & 191 & g9:11 & 표피 & (116 & 1228 & $x$ & 10 & 0823 & 130 \\
\hline cosm & तi & 101 & 3170 & 2057 & 0.23 & 235 & $x$ & $10 \mathrm{~m}$ & 10212 & $2 \pi$ \\
\hline Nonets & $x$ & 6 & 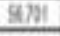 & 4) & 1180 & 80 & $x$ & 1196 & 6er3 & 232 \\
\hline Denter & 31 & 100 & 브래 & 450 & 1110 & 193 & $x$ & iii & 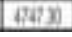 & 171 \\
\hline
\end{tabular}

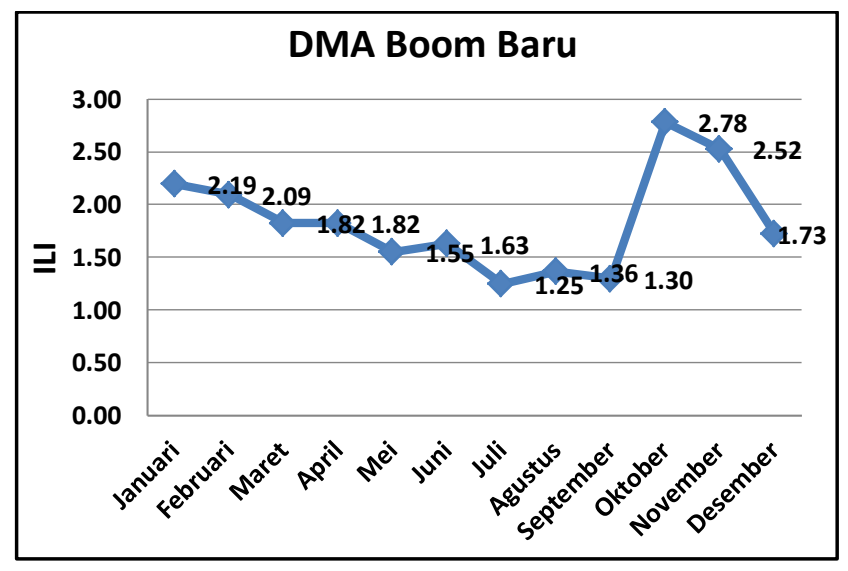

Gambar 3. Nilai ILI DMA Boom Baru

Waktu pengaliran terjadi selama 24 jam/hari, sepanjang tahun 2017 nilai NRW tertinggi terjadi pada bulan Oktober 2017 sebesar $25,54 \%$, sehingga nilai ILI tertinggi pun terjadi pada bulan yang sama sebesar 2,78 . 


\section{DMA Taman Kenten}

DMA Taman Kenten digunakan sejak Agustus 2012, jumlah pelanggan 438 Satuan Layanan dan pendistribusian air $20.815 \mathrm{~m}^{3} /$ det. Tingkat kebocoran di DMA Taman Kenten hingga Desember 2017 sebesar 26,36\%. Berikut ini adalah peta jaringan DMA Taman Kenten:

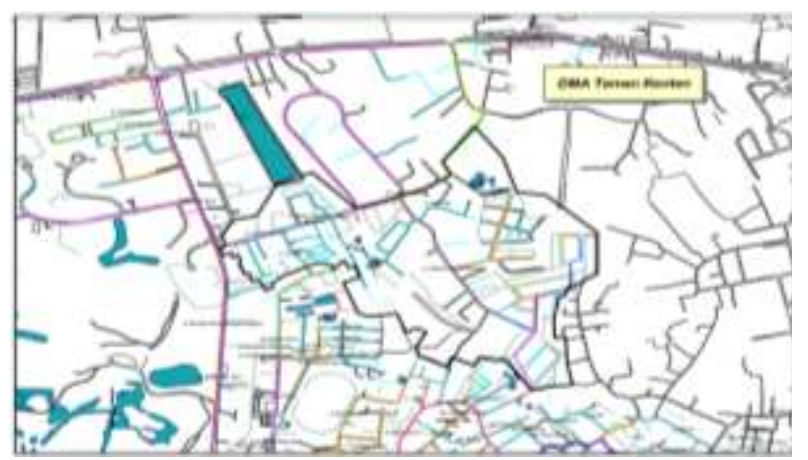

Gambar 4. DMA Taman Kenten

(Sumber : PDAM Tirta Musi,2018)

Tabel 5. NRW dan ILI DMA Taman Kenten

\begin{tabular}{|c|c|c|c|c|c|c|c|c|c|c|}
\hline Bdalen & $\begin{array}{l}\text { Numidh } \\
\text { Horil }\end{array}$ & $\begin{array}{c}\text { Mumiah } \\
\text { Pelaricen }\end{array}$ & $\begin{array}{c}\text { Ait } \\
\text { input }\end{array}$ & Tereiming & $\begin{array}{l}\text { NENE } \\
\text { (m) }\end{array}$ & Maw & $\begin{array}{l}\text { Takanan } \\
\text { toto-ate } \\
(m)\end{array}$ & $\begin{array}{l}\text { cant } \\
\text { (ms) }\end{array}$ & $\begin{array}{l}\text { une: } \\
(\mathrm{m})\end{array}$ & w \\
\hline ianati & $n$ & 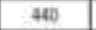 & 40000 & IE, 421 & 7,643 & $11 . \pi$ & 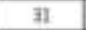 & 7,549 & 67253 & 1.62 \\
\hline Fetruani & 24 & 44 & 26,690 & 17,039 & 7,641 & 3090 & II & 7,511 & 207534 & 1 ․ㅕㅇ \\
\hline Ment & II & 44 & 22,712 & $150 \times 5$ & $7,3 \pi$ & B. & II & $7,6 \mathrm{nn}$ & 47254 & 14 \\
\hline sori & in & $\Delta 1$ & $24,8 \pi$ & 26,350 & 2,001 & 12.7 & In & gen & 472534 & In \\
\hline Me & II & 44 & 5,479 & 17373 & 7,505 & 28.46 & II & 7306 & 277534 & 151 \\
\hline lani & 30 & 441 & 22014 & 16,715 & 5,699 & 25.9 & in & $5,6 \pm 9$ & 20255 & 1.21 \\
\hline hili & II & 441 & 20113 & 14403 & $\$, 730$ & 2139 & 31 & 5.710 & $\cos 54$ & 1.21 \\
\hline Aguita & II & 440 & 21.380 & 16056 & 5,224 & 24.5 & II & 5,524 & 67253 & 121 \\
\hline Sevitemits & 30 & 440 & 22,731 & 17214 & 5,217 & 22.91 & II & 5,117 & 2075.52 & 101 \\
\hline Oktober & 11 & 440 & 20,001 & 15,373 & 3.226 & 25.13 & 31 & 5,228 & 477532 & L.11 \\
\hline Normber & in & 43il & 20287 & 1469 & 5,600 & $27, \pi$ & in & 5,625 & 4785.47 & 124 \\
\hline Denerniter & II & 438 & 20,815 & 15,324 & 5,467 & 26.36 & 31 & 5,452 & $775-40$ & $12 \mathrm{i}$ \\
\hline
\end{tabular}

Sumber : Analisis

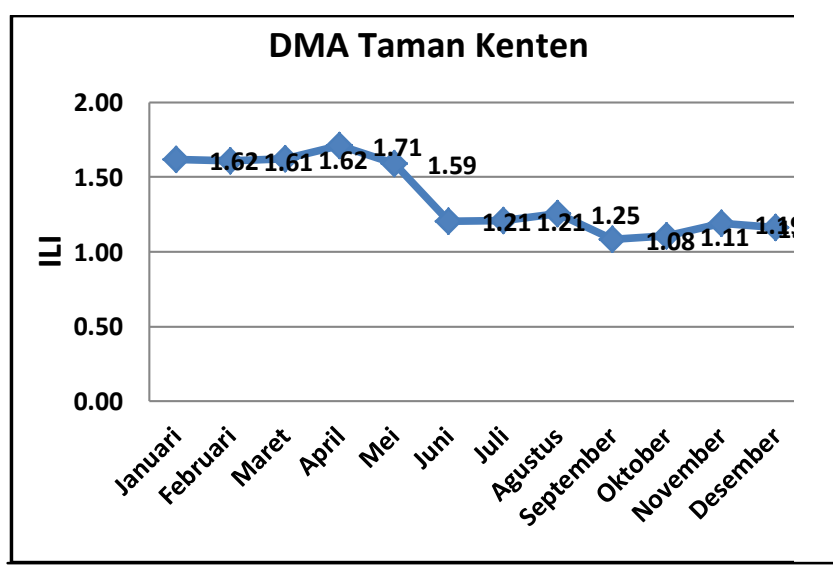

Waktu pengaliran rata-rata 17 jam/hari, NRW terbesar terjadi pada bulan Maret 2017 sebesar 33,80\%. Namun ILI terbesar terjadi pada bulan April sebesar 1,71, dikarenakan kubikasi terbesar kebocoran terjadi pada bulan tersebut.

\section{DMA Sekip Bendung}

DMA Sekip Bendung digunakan sejak Februari 2014, jumlah pelanggan 1.748 Satuan Layanan dan pendistribusian air $73.991 \mathrm{~m}^{3} /$ det. Tingkat kebocoran di DMA Sekip Bendung hingga Desember 2017 sebesar 21,79\%. Berikut ini adalah peta jaringan DMA Sekip Bendung:

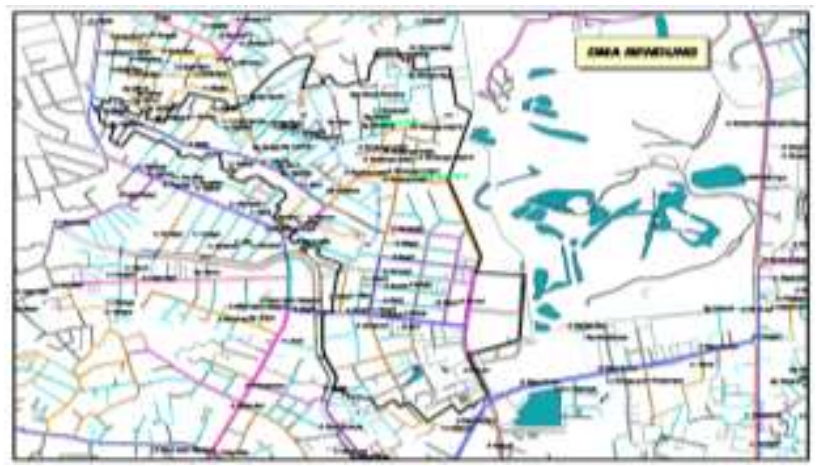

Gambar 6. DMA Sekip Bendung

( Sumber : PDAM Tirta Musi, 2018)

Tabel 6. NRW dan ILI DMA Sekip Bendung

\begin{tabular}{|c|c|c|c|c|c|c|c|c|c|c|}
\hline Alar & himbil & Pelloh & in & Trediening & $\frac{n d s}{|n|}$ & $\frac{\operatorname{sax}}{\mathrm{N}}$ & 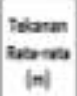 & $\begin{array}{l}\text { cus } \\
\mid \text { |nd } \mid\end{array}$ & 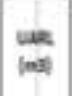 & $w$ \\
\hline honas & II & $17 \mathrm{st}$ & Bas & 8,83 & 2278 & 278 & n2 & 7278 & intes & 234 \\
\hline Renvel & za & $1 \pi x$ & 7. & s:3:1 & 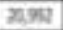 & 78 & 22 & $3 x$ & KSAS5 & 258 \\
\hline Mern & in & $2 \pi 1$ & n.ast & 52611 & $20 \mathrm{e}$ & Dis & II & 2,76 & Kritas & 2.6 \\
\hline 201 & in & $2 / \mathrm{az}$ & 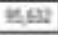 & 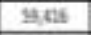 & unit & InI & II & intins & ictose & 43 \\
\hline aw & II & $1 \pi$ & 30 sef & 氜, & 250 & 432 & 22 & 2,54 & Nest5 & 2312 \\
\hline Ini & 30 & 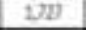 & 7062 & 6osu & 13936 & thin & II & nast & ictiss & 1) \\
\hline $\mathrm{Mi}$ & 표 & $2 \pi m$ & x,tse & se日a & $\mathrm{my}$ & $n a x$ & 72 & 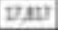 & netass & 221 \\
\hline ferata & II & บี & E4) & 5,06 & 28114 & $2 \pi$ & 22 & IIII4 & ERAS & 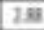 \\
\hline Segtentes & 3 & 1,81 & Xs, 대 & 0.66 & 1350 & $12 \mathrm{~A}$ & 22 & 1452 & Katan & 1 슬 \\
\hline Qentre & II & 12st & 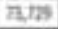 & Hin & $14 \mathrm{an}$ & 25.3 & 22 & $\mathrm{x}=\mathrm{n}$ & Ktag? & $12 x$ \\
\hline Nouenter & 3 & tha1 & 78,594 & ses: & 2518 & 251 & 2 & 15.121 & KEtis? & 121 \\
\hline Denter & II & 1) & $n=1$ & 98 & 1412 & $\pi x$ & 22 & tiftil & intos & 2 III \\
\hline
\end{tabular}

Sumber : Analisis

Gambar 5. Nilai ILI DMA Taman Kenten 


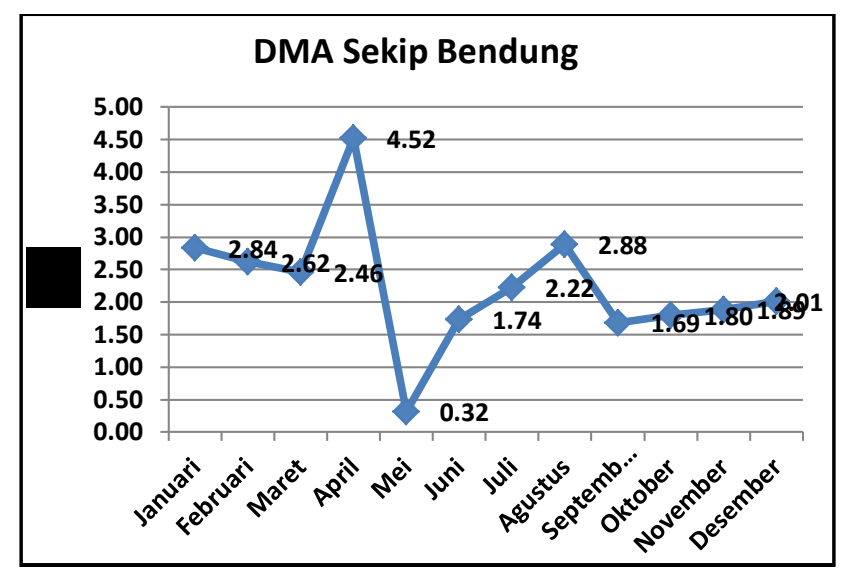

Gambar 7. Nilai ILI DMA Sekip Bendung

Waktu pengaliran selama $24 \mathrm{jam} / \mathrm{hari}$, persentase NRW terbesar terjadi pada bulan Maret 2017 sebesar 37,87\%, sama halnya dengan nilai ILI terbesar yang terjadi pada bulan yang sama sebesar 4,52 .

\section{DMA Kebon Jahe}

DMA Kebon Jahe digunakan sejak Juni tahun 2012, jumlah pelanggan 444 Satuan Layanan dan pendistribusian air sebesar 15.336 $\mathrm{m}^{3} /$ det. Tingkat kebocoran di DMA Kebon Jahe hingga Desember 2017 sebesar 19,34\%. Berikut ini adalah peta jaringan DMA Kebon Jahe:

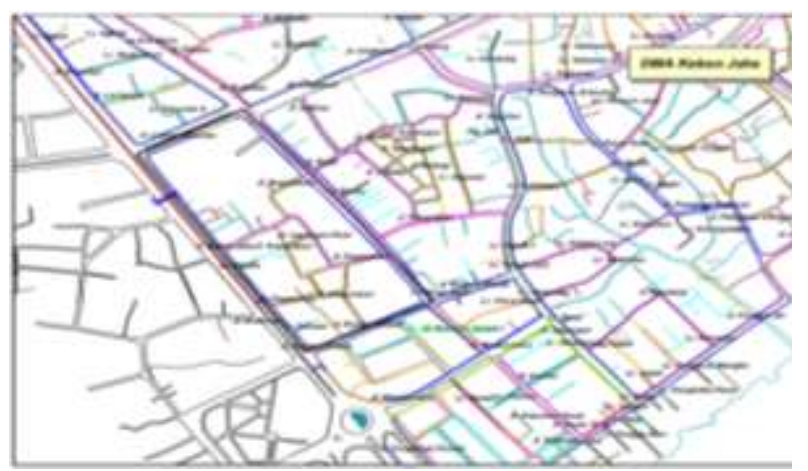

Gambar 8. Peta DMA Kebon Jahe

(Sumber : PDAM Tirta Musi, 2018)
Tabel 7. NRW dan ILI DMA Kebon Jahe

\begin{tabular}{|c|c|c|c|c|c|c|c|c|c|c|}
\hline thin & Samie & $\begin{array}{l}\text { Sumlat } \\
\text { Pelangen }\end{array}$ & avout & Tenients & $\begin{array}{l}\text { Nox } \\
\text { [ms| }\end{array}$ & $\operatorname{san} C \theta$ & 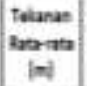 & $\begin{array}{l}\text { cas } \\
|m a|\end{array}$ & $\begin{array}{l}\text { uan } \\
\text { (m) }\end{array}$ & w \\
\hline Imant & it & क⿻ & 15,61 & 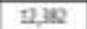 & 369 & $x \omega$ & 5 & 2199 & seng| & 612 \\
\hline fetrami & aㅛ & 4at & 15961 & Bens & 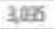 & 1391 & 5 & 20105 & 50गा। & 537 \\
\hline Ment & II & 45 & 13:5 & 2013 & USG & 1330 & 5 & $\operatorname{las}$ & ज्ञाता & Is \\
\hline Asri & 30 & tats & 15,04 & 2,734 & 3,100 & 2478 & 5 & 1,20 & 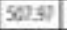 & 6.28 \\
\hline $\mathrm{Me}$ & It & ats & 1458 & 11452 & $\Rightarrow$ & 61 & 5 & 200 & 5046 & 15 \\
\hline ini & $3 x$ & 44 & 13,251 & 12,206 & 䵤 & 0.58 & 5 & SI & र्रा96 & 0.17 \\
\hline 36 & II & 44 & 14600 & nese & 1996 & 1355 & 5 & 1998 & sor 96 & 193 \\
\hline Anese & at & Ast & 15506 & 24,03 & 36 & $6.2 t$ & 5 & 493 & Sx) 96 & $1 \mathrm{~m}$ \\
\hline Septenter & $x$ & 44 & E..1n & 13,006 & 2106 & 1408 & 5 & 2,136 & SND 35 & 471 \\
\hline Oesobre & it & 44 & 15,296 & $13 \times 192$ & 2804 & $14.4 \pi$ & 5 & 2,284 & इ1956 & 43 \\
\hline Noventibe & 32 & 4ht & 2,105 & 20,0 & 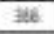 & 283 & 5 & 366 & set36 & 272 \\
\hline Desember & It & 4A4 & D. 3 at & 11, 36 & 2,972 & 23.34 & 5 & 2,972 & 25196] & 18 \\
\hline
\end{tabular}

Sumber : Analisis

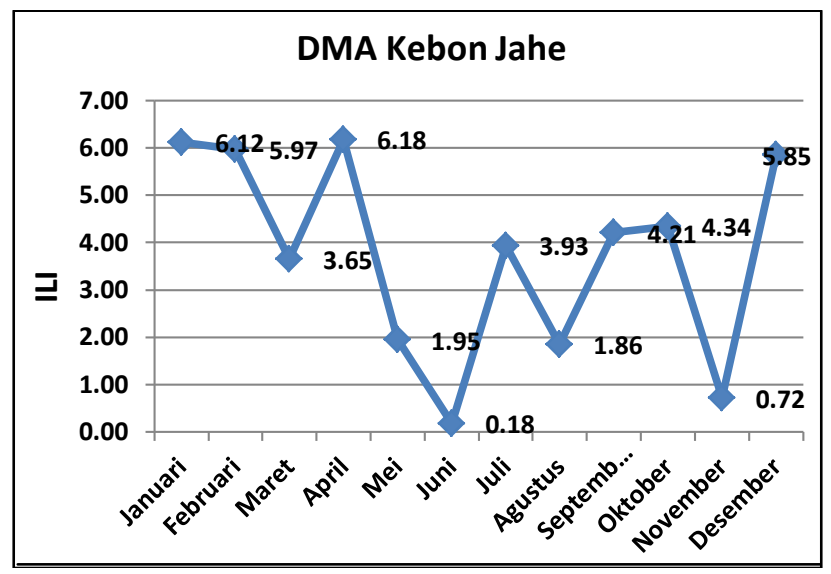

Gambar 9. Nilai ILI DMA Kebon Jahe

Waktu pengaliran selama 12 jam/hari, persentase NRW terbesar terjadi pada bulan Januari 2017 sebesar 20,07\%, sama halnya dengan nilai ILI terbesar yang terjadi di bulan April 2017 sebesar 6,18.

\section{DMA Bambang Utoyo}

DMA Bambang Utoyo digunakan sejak Februari 2012, jumlah pelanggan 1.797 Satuan Layanan dan pendistribusian air 61.450 $\mathrm{m}^{3} /$ det. Tingkat kebocoran di DMA Bambang Utoyo hingga Desember 2017 sebesar 2,08\%. Berikut ini adalah peta jaringan DMA Bambang Utoyo: 


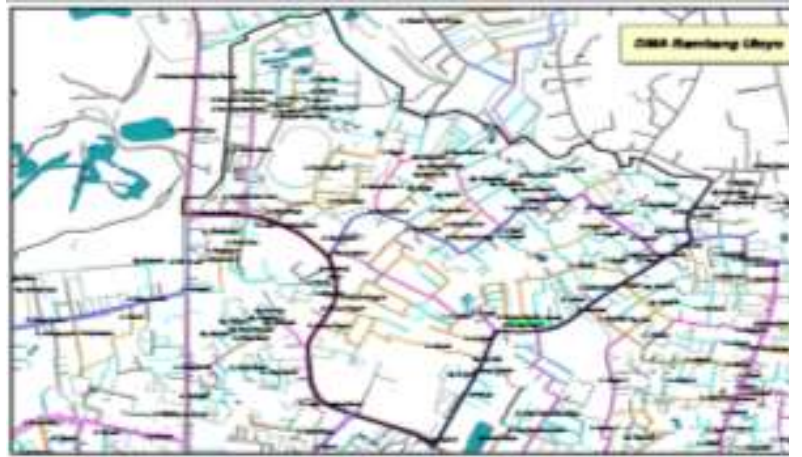

Gambar 10. Peta DMA Bambang Utoyo

(Sumber : PDAM Tirta Musi, 2018)

Tabel 8. NRW dan ILI DMA Bambang Utoyo

\begin{tabular}{|c|c|c|c|c|c|c|c|c|c|c|}
\hline Bdan & $\begin{array}{l}\text { Junlah } \\
\text { Hail }\end{array}$ & $\begin{array}{l}\text { Aumlah } \\
\text { Nwaruesen }\end{array}$ & Arispot & Terobening & $\begin{array}{l}\text { han } \\
\text { (ma) }\end{array}$ & $\begin{array}{l}\text { KRW } \\
\text { DN }\end{array}$ & 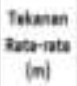 & $\begin{array}{l}\text { CAR } \\
\text { (nI) }\end{array}$ & $\begin{array}{l}\text { Weat } \\
\text { [mal] }\end{array}$ & u \\
\hline Innaw: & 14 & 1,001 & 6,226 & 37,497 & 3,72 & 24.4 & II & 9,727 & gituss & 2.98 \\
\hline Fetriati & $2 i$ & 100 & a, & 36,734 & 2046 & 24.11 & i4 & 9,04 & 22457 & ba \\
\hline Mant & 14 & 1000 & 3,489 & 347.76 & 414 & 1.08 & II & 4,34 & [efos! & 48 \\
\hline bil & 30 & 1,600 & 36,975 & 36,646 & 2,199 & 4.00 & H & 2,159 & Fiates & 20 \\
\hline Viri & 34 & 1,100 & 52,45 & 38.18 & 113 & Q.21 & II & 181 & mises & 0.12 \\
\hline inis & 30 & 1864 & 91,699 & 31,214 & 1935 & $6 \pi$ & HI & 1,065 & 5iase & 397 \\
\hline hí & 14 & 1401 & 56,06 & 32,4 A & 194 & a.2 & 11 & 191 & (1845) & 0.20 \\
\hline Neutus & 14 & 1,79 & 92,610 & 43,362 & $5, \ldots y$ & 12.28 & II & 8956) & 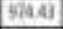 & $11 \mathrm{ins}$ \\
\hline September & 10 & 1,796 & 61,51 & 39.230 & i,Al1 & 10.11 & $n$ & 6,47 & Dinas & 6 iti \\
\hline Datoter & 14 & 1,797 & $36,2 \times$ & 44,490 & 1070 & 1906 & 31 & 10,700 & Giant & 10,4 \\
\hline Nonember & 30 & 1,79 & 99,175 & 34,23 & 2652 & 40 & 3 & 2028 & Ginats & 272 \\
\hline Deientier & 14 & $1, \pi /$ & 61,48 & $\omega . \omega 6$ & 1,211 & 2.86 & 31 & 1,297 & 574.41 & 14 \\
\hline
\end{tabular}

Sumber : Analisis

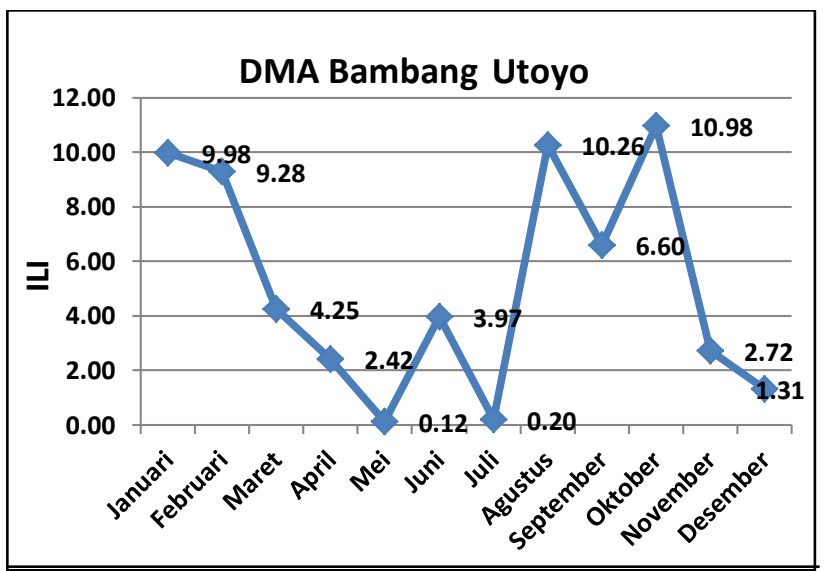

Gambar 11. Nilai ILI DMA Bambang Utoyo

Waktu pengaliran selama 8 jam/hari, persentase NRW terbesar terjadi pada bulan Oktober 2017 sebesar 19,06\%, sama halnya dengan nilai ILI terbesar yang terjadi di bulan Oktober 2017 sebesar 10,98.

\section{DMA Duku Kanan}

DMA Duku Kanan digunakan sejak Januari 2013, jumlah pelanggan 1.992 Satuan Layanan dan pendistribusian air sebesar 80689 $\mathrm{m}^{3} /$ det. Tingkat kebocoran di DMA Duku
Kanan hingga Desember 2017 sebesar 7,31\%. Berikut ini adalah peta jaringan DMA Duku Kanan:

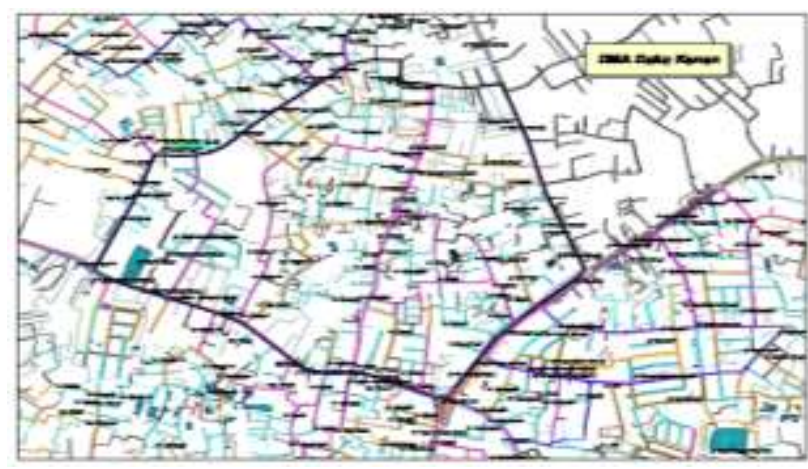

Gambar 12. Peta DMA Duku Kanan

(Sumber : PDAM Tirta Musi, 2018)

Tabel 10. NRW dan ILI DMA Duku Kanan

\begin{tabular}{|c|c|c|c|c|c|c|c|c|c|c|}
\hline Butan & $\begin{array}{l}\text { lumizh } \\
\text { Hent }\end{array}$ & 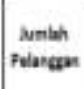 & lepat & Teniening & $\begin{array}{l}\text { naw } \\
|\mathrm{m} 3|\end{array}$ & nетеу & 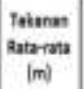 & $\begin{array}{l}\text { CAst } \\
\text { [m3] }\end{array}$ & $\begin{array}{l}\text { UAAB } \\
\text { |m3\}| }\end{array}$ & uu \\
\hline inuari & II & $\overline{m 2}$ & 28,419 & 61,414 & 19,001 & 2106 & 22 & 190,001 & 7260 & 2.52 \\
\hline Fienraif & $\bar{z}$ & $\mathrm{mi}$ & 71312 & 8 & 5,154 & & 22 & 6,34 & 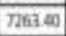 & 0.7 \\
\hline Maret & II & 2000 & $f_{1}, x_{5}$ & 234 & 7,111 & $\pm 1 . n$ & $\bar{n}$ & 7,411 & 72613 & 1017 \\
\hline Maik & 10 & 1998 & 79,900 & a. 34 & 14616 & 5.28 & 22 & 34,516 & $7 x_{2} 34$ & 201 \\
\hline me & II & $5 m$ & 70,269 & Gings & 13,243 & \begin{tabular}{|l|l|}
1737 \\
\end{tabular} & 22 & 13,241 & 78 ing & 1.12 \\
\hline int & 30 & 1.99 & 뵤477 & 6362 & 510210 & A3II & 22 & $.50,280$ & $7 \pi 63$ & $4.4 !$ \\
\hline$\lambda i$ & 31 & 1995 & 70,907 & 393 & 13,594 & 17.000 & 22 & 13,594 & $78 x_{1}$ & 137 \\
\hline Аyintu & II & 1,998 & 82,45 & $640 \mathrm{~ms}$ & 11254 & $21 \mathrm{AI}$ & & 18,44 & 766394 & 234 \\
\hline Sophaniber & 30 & $2 m$ & 70,006 & a) 216 & $8,77 t$ & 11.57 & 27 & B,, $3 \%$ & 78631 & 121 \\
\hline denaber & 11 & 1925 & ingin? & 5496 & 15,639 & 28.32 & 22 & 15,039 & 7 Fin & 297 \\
\hline Noverber & 36 & 1.995 & Eist 47 & $\sin 2$ & 14 政 & 17.72 & $n$ & 30,749 & 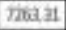 & 204 \\
\hline 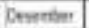 & 71 & 199 & 82,609 & 7474 & 5,895 & 7.11 & 22 & 5,6066 & 76024 & 691 \\
\hline
\end{tabular}

Sumber : Analisis

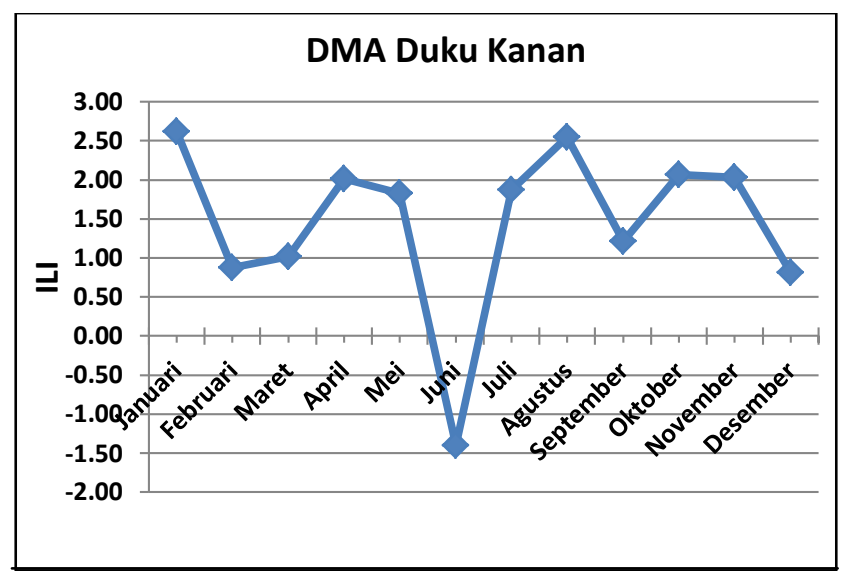

Gambar 13. Nilai ILI DMA Duku Kanan

Waktu pengaliran selama 7 jam/hari, persentase NRW terbesar terjadi pada bulan Januari 2017 sebesar 23,06\% sama halnya dengan nilai ILI terbesar yang terjadi di bulan Januari 2017 sebesar 2,62. 


\section{DMA Sungai Batang}

DMA Sungai Batang mulai digunakan sejak Oktober 2015, jumlah pelanggan 3.211 Satuan Layanan dan pendistribusian air sebesar $108.409 \mathrm{~m}^{3} /$ det. Tingkat kebocoran di DMA Sungai Batang hingga Desember 2017 sebesar $5,04 \%$. Berikut peta jaringan DMA Sungai Batang:

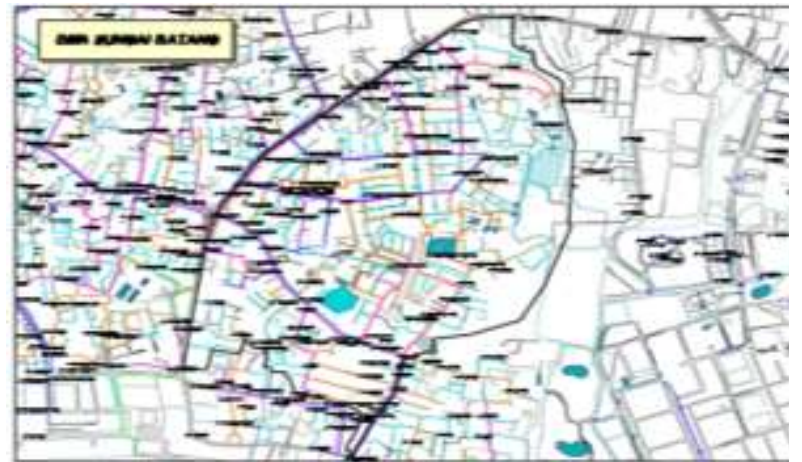

Gambar 14. Peta DMA Sungai Batang

(Sumber : PDAM Tirta Musi, 2018)

Tabel 10. NRW dan ILI Sungai Batang

\begin{tabular}{|c|c|c|c|c|c|c|c|c|c|c|}
\hline Alan & $\begin{array}{l}\text { liamith } \\
\text { Mant }\end{array}$ & $\begin{array}{l}\text { homiah } \\
\text { Pearnegen }\end{array}$ & $\stackrel{A v}{\text { lapot }}$ & Terobining & $\begin{array}{l}\text { NaW } \\
\left\langle m\left|{ }^{\prime}\right|\right.\end{array}$ & sewiv & 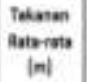 & $\begin{array}{l}\text { Catt } \\
\text { (an) }\end{array}$ & $\begin{array}{l}\text { ueat } \\
\text { |m1| }\end{array}$ & in \\
\hline lanus & 11 & 1,111? & {$[12,484$} & insms & 7,4 in & 6.64 & 2 & $y, A \in A$ & 15218 & th18 \\
\hline Fibraif & an & 1214 & 125,066 & $100 \pi$ गा & 2.396 & 104 & $x$ & 24,000 & BSIM & 2.15 \\
\hline Mest & III & 1.213 & 12,220 & 72,499 & 1048 & $17 \times$ & In & 20400 & Bम2. & 2.8 \\
\hline 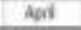 & 10 & 1,214 & [10.02 & $102 \times 19$ & 12,94 & 1424 & $n$ & D.834 & BMIM & 200 \\
\hline Wri & II & 1,715 & {$[9,27]$} & m,in & 1635 & 156 & $n$ & 18,36 & 1522.90 & 218 \\
\hline $\lim$ & 10 & 2.214 & 154,27 & 102.245 & 51986 & 20 & $n$ & 51,776 & 522190 & 630 \\
\hline ini & II & $1, \mathrm{~min}$ & 11,660 & tox. & $m, 71$ & in & $\bar{x}$ & $8, \pi$ & 1522.94 & 2.51 \\
\hline Matha & in & 1,215 & 120,432 & พ.419 & $10 \mathrm{~min}$ & $2 N$ & $x$ & 12, 13 & BSII. & 2.17 \\
\hline Sephomian & in & 1,215 & 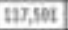 & (17),97 & 9,65 & 121 & $n$ & 9,557 & ह22. & I.II \\
\hline Oeduter & 11 & 1,275 & 19,28 & 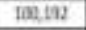 & 1309 & 1152 & $n$ & 13,051 & BSID & 13 \\
\hline Nevember & 10 & 1,1215 & 120,290 & 19055 & 1.39 & 247 & 2 & 5297 & 650.96 & 69 \\
\hline Desember & II & 1,211 & 20,413 & 国些 & $1,4 \mathrm{II}$ & 104 & zi & 9,462 & EN2.00 & 0.4 \\
\hline
\end{tabular}

Sumber : Analisis

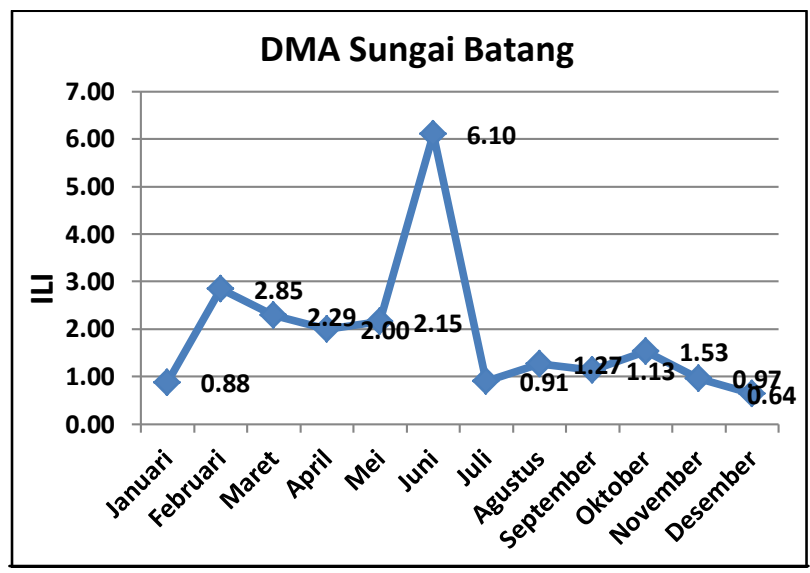

Gambar 15. Nilai ILI DMA Sungai Batang

Waktu pengaliran selama 7 jam/hari, persentase NRW terbesar terjadi pada bulan
Juni 2017 sebesar 33,69\%, sama halnya dengan nilai ILI terbesar yang terjadi di bulan Januari 2017 sebesar 6,10.

\section{DMA Mangkubumi}

DMA Mangkubumi mulai digunakan sejak Februari 2012, jumlah pelanggan 1.342 Satuan Layanan dan pendistribusian air sebesar $56.291 \mathrm{~m}^{3} /$ det.Tingkat kebocoran di DMA Mangkubumi hingga Desember 2017 sebesar $19,89 \%$.Berikut peta jaringan DMA Mangkubumi:

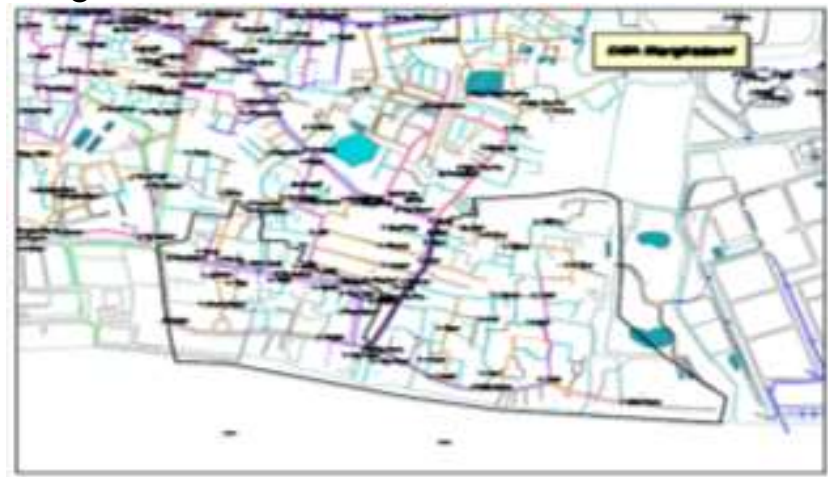

Gambar 16. Peta DMA Mangkubumi (Sumber : PDAM Tirta Musi, 2018)

Tabel 11. NRW dan ILI DMA Mangkubumi

\begin{tabular}{|c|c|c|c|c|c|c|c|c|c|c|}
\hline Bulen & $\begin{array}{c}\text { Juminh } \\
\text { Meri }\end{array}$ & $\begin{array}{l}\text { hambin } \\
\text { rotumes: }\end{array}$ & $\begin{array}{c}\text { Ain } \\
\text { input }\end{array}$ & Feretering & $\begin{array}{l}\text { Ninw } \\
\text { [mil| }\end{array}$ & newowa & $\begin{array}{c}\text { Toikns } \\
\text { anes: } \\
\text { mat } \\
\text { (e) }\end{array}$ & $\begin{array}{l}\text { cani } \\
\text { imsi }\end{array}$ & $\begin{array}{l}\text { inat } \\
\text { ims! }\end{array}$ & n \\
\hline Iemani & 31 & 1,285 & 55,2610 & $44 x 4$ & 30.92 & $19 n$ & a & 10.92 & Sथय. & 211 \\
\hline folnew & W & 1,19 & 59,000 & 45. & 0.55 & 1640 & 2 & 9135 & \$123.6 & $1 \mathrm{~N}$ \\
\hline Mare & I & 1,31 & 55,344 & 41,17 & 21 ini? & 28 & aia & 12, 197 & sms. & 2.6 \\
\hline Anil & 勿 & 1,201 & 58,120 & 45,200 & $\$ .131$ & 10.16 & 2is & 5.111 & Мग.:日 & 100 \\
\hline $\mathrm{Mei}$ & II & 1,94 & 51,23 & 45.623 & 3596 & $10 n$ & an & 5396 & Sal. & 1.67 \\
\hline Anei & 90 & 1,92 & 46.62 & 02,24 & 6.34 & 127 & a & 6.204 & 51270 & 17 \\
\hline Mat & II & 1,42 & 58.92 & 45. $3 \mathrm{mi}$ & 3.301 & 12.22 & $a$ & 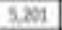 & Sथा. & 100 \\
\hline Ауанй & it & 1,122 & 32.25 & 4556 & IASS & Bal & a & QASs & Sime & 1.6A \\
\hline leptinites] & ta & 1.242 & 32,50 & 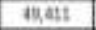 & 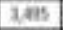 & S.ti & 23 & 1455 & S27. & De. \\
\hline oniber & it & 1,32 & 22,173 & 42,2021 & 0.32 & 19n & 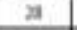 & 2.212 & $\sin , \mathrm{s}^{2}$ & 1.II \\
\hline Noventer & 10 & 1,24 & 36,196 & AL23 & 30.162 & 19.40 & $\nexists$ & 30102 & 522.8 & 160 \\
\hline enth & & 18 & & 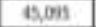 & 1.196 & 79 & & 11.196 & 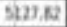 & 21 \\
\hline
\end{tabular}

Sumber : Analisis

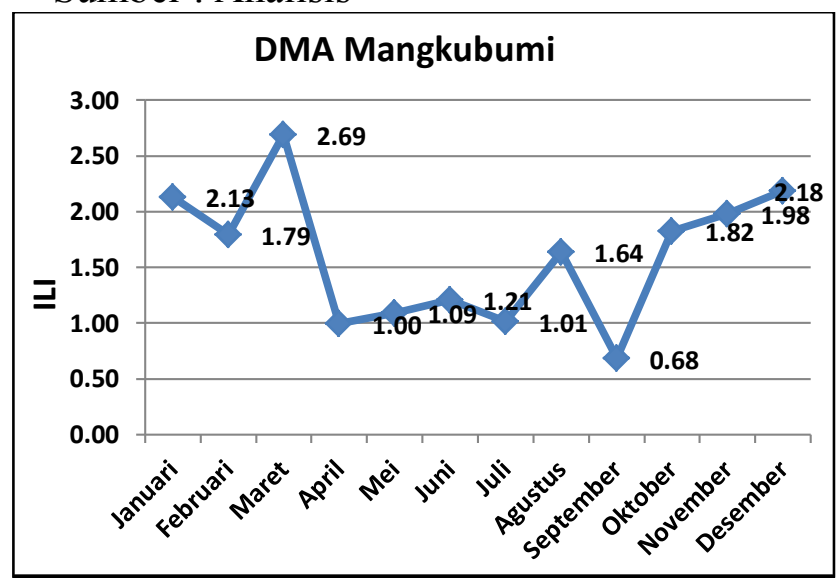

Gambar 17. Nilai ILI DMA Sungai Batang 
Waktu pengaliran selama $12 \mathrm{jam} / \mathrm{hari}$. persentase NRW terbesar terjadi pada bulan Desember 2017 sebesar $19,89 \%$ sama halnya dengan nilai ILI terbesar yang terjadi di bulan Maret 2017 sebesar 2,69.

\section{DMA Penyaringan}

DMA Penyaringan mulai digunakan sejak Mei 2011, jumlah pelanggan 1.394 Satuan Layanan dan pendistribusian air sebesar $67.902 \mathrm{~m}^{3} /$ det. Tingkat kebocoran di DMA Penyaringan hingga Desember 2017 sebesar $27,08 \%$. Berikut ini adalah peta jaringan DMA Penyaringan:

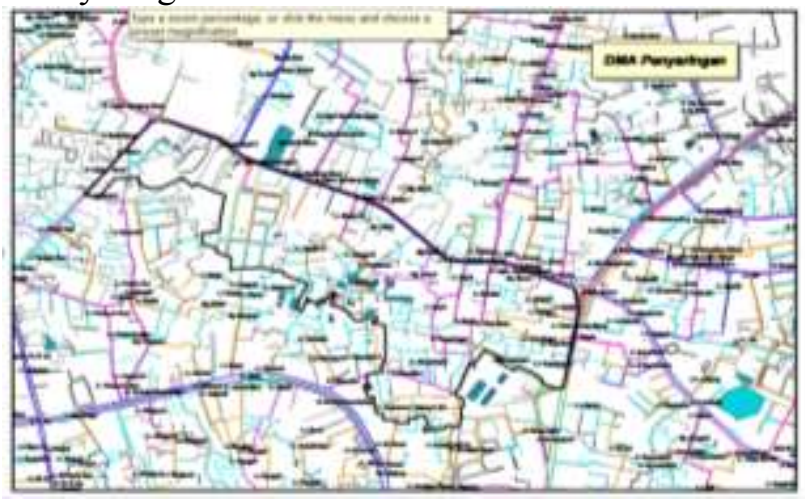

Gambar 18. Peta DMA Penyaringan

(Sumber : PDAM Tirta Musi, 2018)

Tabel 12. NRW dan ILI DMA Penyaringan

\begin{tabular}{|c|c|c|c|c|c|c|c|c|c|c|}
\hline Bàn & $\begin{array}{l}\text { Marriak } \\
\text { lail }\end{array}$ & $\begin{array}{l}\text { limish } \\
\text { Nareses }\end{array}$ & $\underset{n a t}{40}$ & Inetoris: & 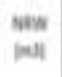 & hascen| & 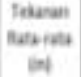 & $\begin{array}{l}\text { ant } \\
\text { indi }\end{array}$ & ast & 6 \\
\hline inan: & in & L.in & 12/45 & $40 \mathrm{st}$ & tose & $8 x$ & $\pi$ & 1156 & insere & 1 ia \\
\hline Rowat & in & 1.96 & 84.45 & a. 54 & $5 \times 2$ & 268 & $\pi$ & $1586 t$ & $\operatorname{tas} 20$ & $E m$ \\
\hline Mant & II & Lin & 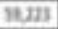 & atsw & 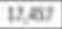 & $8 a$ & $n$ & iㅏ를 & 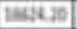 & in \\
\hline Aque & iv & 1,10 & 6112 & ati & 17 sa & 89 & $\pi$ & D, & 13000 & 18 \\
\hline N4 & $\pi$ & 1,60 & 360 & $\operatorname{sen} 2$ & Late & $2 n$ & 78 & nen & 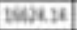 & 29 \\
\hline anis & is & L.mi & atio & ats & Dins & 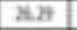 & 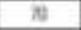 & $12 \times 5$ & 1 & 13 \\
\hline 36 & II & 1.16 & กา & 4(1) & 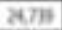 & $\mu f$ & $\pi$ & 207 & $168+60$ & 16 \\
\hline touts & II & 1,25 & $n .04$ & 434 & 2016 & 픈 & $x$ & 20\% & Eans? & 16 \\
\hline Selatuter & 10 & L. & R.att & 5214 & zos4 & 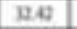 & $\pi$ & 284 & 1652.9. & 131 \\
\hline weits & H & 1., & n.10 & 4224 & RE? & $4 \pi$ & $n$ & 280 & 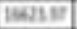 & $1 \%$ \\
\hline Knamber & 10 & L.1.4 & $n \geq 20$ & 20529 & $18 \mathrm{ans}$ & 813 & $\pi$ & tatele & tangen & 111 \\
\hline Dinnnter & in & L, 194 & 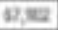 & 2034 & 18.13 & ma & $\pi$ & in & taices & L.tI \\
\hline
\end{tabular}

Sumber : Analisis

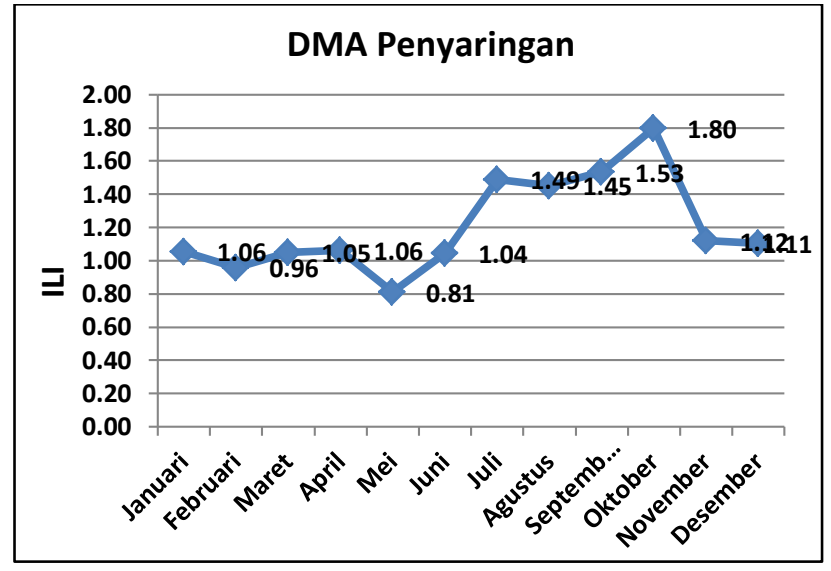

Gambar 19. Nilai ILI DMA Penyaringan

Waktu pengaliran selama 17 jam/hari, persentase NRW terbesar terjadi pada bulan Oktober 2017 sebesar 38,77\%, sama halnya dengan nilai ILI terbesar yang terjadi di bulan Oktober 2017 sebesar 1,80.

\section{DMA Veteran 1}

DMA Veteran mulai digunakan sejak Desember 2010 dengan jumlah pelanggan 593 Satuan Layanan dan pendistribusian air sebesar $27670 \mathrm{~m}^{3} /$ det. Tingkat kebocoran di DMA Veteran 1 hingga Desember 2017 sebesar $20,25 \%$. Berikut ini peta jaringan DMA Veteran:

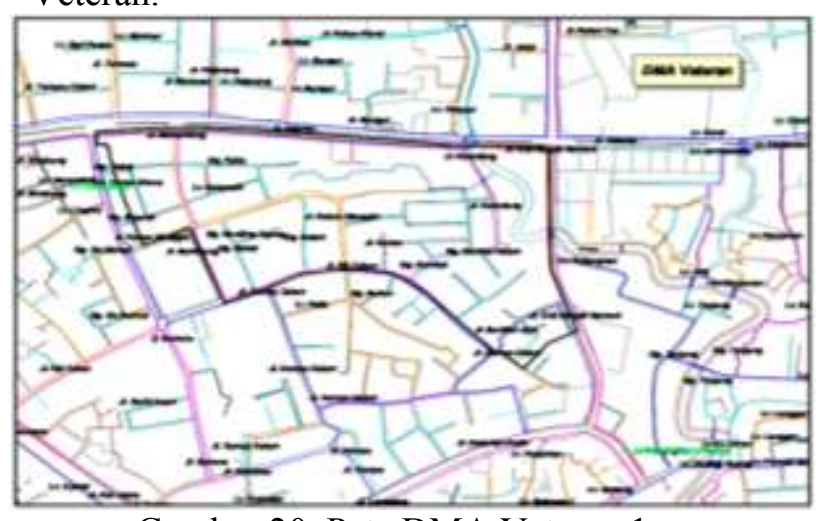

Gambar 20. Peta DMA Veteran 1

(Sumber : PDAM Tirta Musi, 2018) 
Tabel 13. NRW dan ILI DMA Veteran 1

\begin{tabular}{|c|c|c|c|c|c|c|c|c|c|c|}
\hline Buam & $\begin{array}{l}\text { innivas } \\
\text { Meif }\end{array}$ & $\begin{array}{l}\text { Mundat } \\
\text { Noweren }\end{array}$ & ${ }_{\text {and }}^{\text {Ast }}$ & Tedeieves & $\begin{array}{l}\text { naw } \\
\text { inaij }\end{array}$ & shwow! & 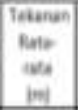 & $\begin{array}{l}\text { chat } \\
\text { imat }\end{array}$ & $\begin{array}{l}\text { uani } \\
\text { intin }\end{array}$ & $\mu$ \\
\hline Dhasi & $n$ & 69 & 9,8в & 2010 & 16.9I & 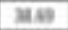 & $n$ & 1434 & 3014.5 & 47 \\
\hline Gatrani & 28 & MT & 31,39 & 259 & 1102 & प्र.45 & $2 \pi$ & $13,96 ?$ & 30162 & 405 \\
\hline Ment & 31 & 5 thi & KIIII & 21,415 & 11,76 & 504 & $n$ & 11716 & 341450 & 402 \\
\hline koi & in & 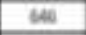 & n.12 & 21590 & 21,41 & 200 & $n$ & 114011 & 34140 & 10 \\
\hline W & 14 & 644 & 02,50 & 2016 & 10ut & 6.11 & $n$ & 16.201 & 344016 & 474 \\
\hline in & 31 & 64 & n.5e & संख्या & 13,65 & 40 & $n$ & 13986 & Hathe & 525 \\
\hline hi & 4 & $\omega$ & 12,41 & zon & a.12 & $2 n$ & $z$ & in & 3445 & $2 n$ \\
\hline Weath & II & $4 \pi$ & 2144 & 2100 & $3,7 \mathrm{n}$ & 13.15 & $n$ & 3.75 & 3448 & 1.5 \\
\hline Keiturile & 10 & 43 & 2.59 & 2609 & 0.75 & 16.11 & 2 & 4.26 & 3445 & 16 \\
\hline Contri & 11 & 60 & 20,56 & 2621 & 4.15 & 15.51 & 22 & $4.1 \mathrm{~K}$ & 34485 & 17 \\
\hline Neremben & 10 & 50 & 21,511 & 21.00 & 5.494 & 2101 & $n$ & 4.61 & 3415 & $1 \times$ \\
\hline Dosenter & in & 300 & $27,5 \pi$ & 2200 & 3,102 & 2078 & $n$ & 1402 & 3419: & 1.64 \\
\hline
\end{tabular}

Sumber : Analisis

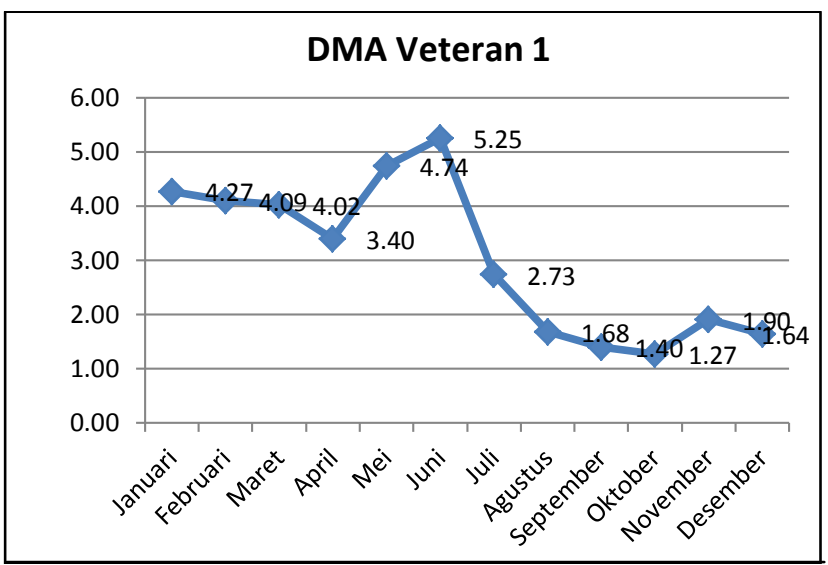

Gambar 21. Nilai ILI DMA Veteran 1

Waktu pengaliran selama 17 jam/hari, persentase NRW terbesar terjadi pada bulan Juni 2017 sebesar 44,98\% sama halnya dengan nilai ILI terbesar yang terjadi di bulan Juni 2017 sebesar 5,25.

\section{Analisis ILI DMA Unit 3 Ilir}

Setelah dilakukan perhitungan setiap DMA pada unit 3 Ilir maka diambil nilai ILI terbesar sebagai indkator kinerja DMA. Berikut ini adalah hasil perhitungan nilai ILI yang ada di setiap DMA yaitu : DMA Veteran 1, Boom Baru, Penyaringan, Sekip Bendung, Kebon Jahe, Mangkubumi, Bambang Utoyo, Duku Kanan, Taman Kenten, dan Sungai Batang.

Tabel 14. Nilai ILI Terbesar Unit 3 Ilir

\begin{tabular}{|c|c|c|}
\hline NO & LOKASI DMA & ILI \\
\hline 1 & VETERAN I & 5.25 \\
2 & BOOM BARU & 2.78 \\
3 & PENYARINGAN & 1.80 \\
4 & SEKIP BENDUNG & 4.52 \\
5 & KEBON JAHE & 6.18 \\
\hline
\end{tabular}

\begin{tabular}{|c|c|} 
MANGKUBUMI & 2.69 \\
BAMBANG UTOYO & 10.98 \\
DUKU KANAN & 2.62 \\
TAMAN KENTEN & 1.78 \\
SUNGAI BATANG & 6.10
\end{tabular}

Sumber : Analisis

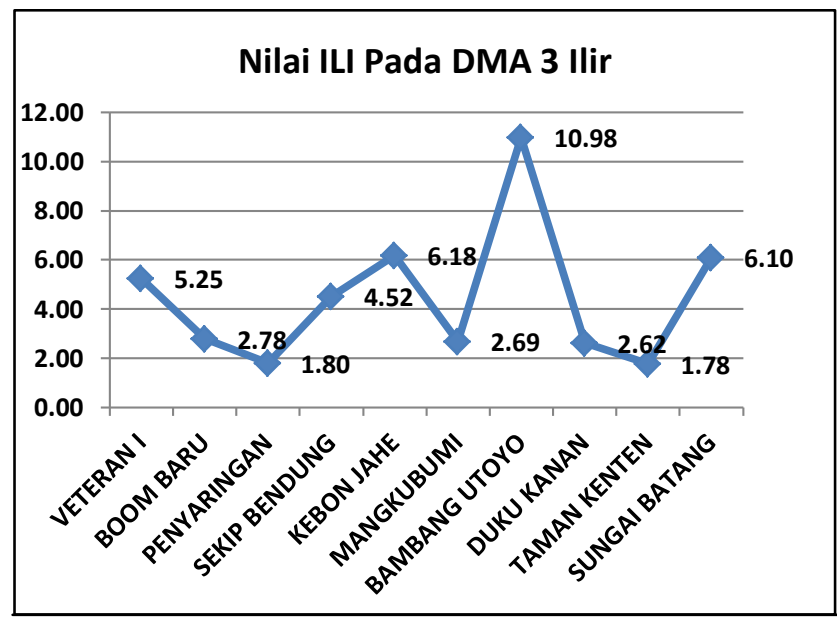

Gambar 4.11. ILI Terbesar di DMA Unit 3 Ilir

Dari grafik diatas dapat dilihat angka tertinggi NRW terdapat pada DMA Bambang Utoyo sebesar 10,98. Dari nilai tersebut kemudian dihubungkan dengan tabel matriks target yang dapat dilihat pada tabel 15 berikut :

Tabel 15. Matriks Target

\begin{tabular}{|c|c|c|c|c|c|c|c|}
\hline \multirow{4}{*}{$\begin{array}{l}\text { Kate- } \\
\text { gori }\end{array}$} & \multirow{4}{*}{$\begin{array}{l}\text { Kinerja } \\
\text { Teknis }\end{array}$} & \multirow{4}{*}{ ILI } & \multirow{2}{*}{\multicolumn{5}{|c|}{$\begin{array}{c}\text { Kehilangan Fisik (liter/sambungan/hari) } \\
\text { Keadaan sistem bertekanan pada }\end{array}$}} \\
\hline & & & & & & & \\
\hline & & & \multicolumn{5}{|c|}{ tekanan rata-rata } \\
\hline & & & $10 \mathrm{~m}$ & $20 \mathrm{~m}$ & $30 \mathrm{~m}$ & $40 \mathrm{~m}$ & $50 \mathrm{~m}$ \\
\hline \multirow[t]{4}{*}{$\begin{array}{c}\text { Negara } \\
\text { Maju }\end{array}$} & $\mathrm{A}$ & $\begin{array}{c}1- \\
2 \\
\end{array}$ & & $<50$ & $<75$ & $<100$ & $<125$ \\
\hline & $B$ & $\begin{array}{c}2- \\
4\end{array}$ & & $\begin{array}{l}50- \\
100\end{array}$ & $\begin{array}{l}75- \\
100\end{array}$ & $\begin{array}{l}100- \\
200\end{array}$ & $\begin{array}{l}125- \\
250\end{array}$ \\
\hline & C & $\begin{array}{c}4- \\
8\end{array}$ & & $\begin{array}{l}100- \\
200\end{array}$ & $\begin{array}{l}150- \\
300\end{array}$ & $\begin{array}{l}200- \\
400\end{array}$ & $\begin{array}{c}250- \\
500\end{array}$ \\
\hline & D & $>8$ & & $>200$ & $>300$ & $>400$ & $>500$ \\
\hline \multirow{4}{*}{$\begin{array}{c}\text { Negara } \\
\text { Sedang } \\
\text { Berkem } \\
\text {-bang }\end{array}$} & $\mathrm{A}$ & $\begin{array}{c}1- \\
4\end{array}$ & $<50$ & $<100$ & $<150$ & $<200$ & $<250$ \\
\hline & B & $\begin{array}{c}4- \\
8\end{array}$ & $\begin{array}{l}50- \\
100\end{array}$ & $\begin{array}{l}100- \\
200\end{array}$ & $\begin{array}{l}150- \\
300\end{array}$ & $\begin{array}{l}200- \\
400\end{array}$ & $\begin{array}{c}250- \\
500\end{array}$ \\
\hline & C & $\begin{array}{l}8- \\
16\end{array}$ & $\begin{array}{l}100- \\
200\end{array}$ & $\begin{array}{l}200- \\
400\end{array}$ & $\begin{array}{l}300- \\
600\end{array}$ & $\begin{array}{c}400- \\
800\end{array}$ & $\begin{array}{l}500- \\
1000\end{array}$ \\
\hline & $\mathrm{D}$ & $\begin{array}{l}>1 \\
6\end{array}$ & $>200$ & $>400$ & $>600$ & $>800$ & $\begin{array}{c}> \\
1000\end{array}$ \\
\hline
\end{tabular}

Sumber : (DPU BPPS PAM : 2008)

Berdasarkan tabel 15 diatas, matriks target dengan nilai ILI 10,98 maka DMA Unit 3 Ilir termasuk kategori kelas C, yang indikatornya dapat dilihat pada tabel 16 dibawah ini: 
Tabel 16. Indikator Kategori Matriks Target

\begin{tabular}{|c|l|}
\hline A & $\begin{array}{l}\text { Upaya penurunan kehilangan air tidak ekonomis } \\
\text { kecuali ada kekurangan pasokan; analisis yang } \\
\text { cermat diperlukan untuk identifikasi perbaikan } \\
\text { yang ekonomis }\end{array}$ \\
\hline B & $\begin{array}{l}\text { Potensial untuk dilakukan perbaikan; coba } \\
\text { pengaturan tekanan; penanganan kebocoran } \\
\text { secara aktif; dan peningkatan pemeliharaan } \\
\text { jaringan }\end{array}$ \\
\hline C & $\begin{array}{l}\text { Pencatatan kebocoran yang buruk; hanya dapat } \\
\text { ditoleransi bila airnya berlimpah dan murah; } \\
\text { meskipun begitu, harus tetap dianalisis tingkat } \\
\text { dan penyebab kebocoran dan intensifkan upaya } \\
\text { penurunan kebocoran }\end{array}$ \\
\hline D & $\begin{array}{l}\text { Pemborosan sumberdaya secara luar biasa; } \\
\text { program penurunan kebocoran harus } \\
\text { diprioritaskan. }\end{array}$ \\
\hline
\end{tabular}

Sumber : (DPU BPPS PAM : 2008)

\section{Analisis Kepuasan Pelanggan Setelah Pemasangan DMA}

Untuk mengetahui respon konsumen setelah pemasangan DMA, maka dilakukan penelitian tingkat kepuasan. Dari 10 (sepuluh) DMA yang ada di Unit 3 Ilir, diambil DMA Taman Kenten sebagai sampel karena DMA Taman Kenten merupakan DMA yang memiliki nilai ILI terkecil dari keseluruhan DMA Unit 3 Ilir PDAM Tirta Musi Palembang, yaitu sebesar 1,71.

Jumlah sambungan PDAM Tirta Musi Palembang di wilayah DMA Taman Kenten adalah 438 Sambungan Layanan (SL), sehingga berdasarkan jumlah populasi sambungan layanan dapat diambil sampel sebanyak 81 sampel, yang perhitungannya berdasarkan rumus Slovin :

$$
\mathrm{n}=438 /\left(1+438 \times 0.1^{2}\right)=81,3 \cong 81 \text { sampel }
$$

Diambil 81 sampel responden yang mewakili untuk di data pada kuesioner.

\section{Skoring Data}

Setelah Responden dipetakan, maka dilakukan wawancara langsung dengan menggunakan kuisioner yang telah dibuat, lalu dilakukan skoring untuk masing-masing pertanyaan. Pemberian skoring ini dimaksudkan untuk mempermudah dalam proses tabulasi.

Tabel 17. Tingkat Kepuasan Berdasarkan

Skoring Jawaban

\begin{tabular}{|c|c|}
\hline No & Kategori \\
\hline 1 & Sangat Tidak Puas \\
\hline 2 & Tidak Puas \\
\hline
\end{tabular}

\begin{tabular}{|c|c|}
\hline 3 & Cukup Puas \\
\hline 4 & Puas \\
\hline 5 & Sangat Puas \\
\hline
\end{tabular}

Sumber : Pengolahan Data

\section{Pengolahan Data}

Setelah dilakukan wawancara dengan pelanggan, kemudian dilakukan proses pengumpulan data dan tabulasi data, kemudian dilanjutkan dengan pengolahan data dengan menggunakan SPSS 22.0.

Hasil rekapitulasi skoring kuesioner yang dilakukan pada 81 orang pelanggan PDAM Tirta Musi yang berada pada DMA Taman Kenten Unit 3 Ilir Palembang.

Tabel 18. Rekapitulasi Skoring Kuisioner

\begin{tabular}{|c|c|c|c|c|c|c|c|}
\hline $\begin{array}{l}\mathbf{N} \\
\mathbf{0}\end{array}$ & Pertanyaan & 1 & 2 & 3 & 4 & 5 & $\begin{array}{c}\text { Juml } \\
\text { ah }\end{array}$ \\
\hline 1 & $\begin{array}{l}\text { Bagaimana tigkat kepuasan } \\
\text { anda terhadap debit air bersih } \\
\text { yang keluar di kran rumah } \\
\text { anda dalam memenuhi } \\
\text { kebutuhan sehari-hari }\end{array}$ & 1 & 1 & 19 & 50 & 10 & 81 \\
\hline 2 & $\begin{array}{l}\text { Bagaimana tingkat kepuasan } \\
\text { anda terhadap warna air } \\
\text { bersih yang keluar di mkran } \\
\text { rumah anda dalam memenuhi } \\
\text { kebutuhan sehari-hari }\end{array}$ & 0 & 0 & 11 & 43 & 27 & 81 \\
\hline 3 & $\begin{array}{l}\text { BAgaimana tingkat kepuasan } \\
\text { anda terhadap bau air bersih } \\
\text { yang keluar di kran rumah } \\
\text { anda dalam memenuhi } \\
\text { kebutuhan sehari-hari }\end{array}$ & 0 & 0 & 13 & 47 & 21 & 81 \\
\hline 4 & $\begin{array}{l}\text { Bagaimana tingkat kepuasan } \\
\text { anda terhadap kontinuitas } \\
\text { debit air bersih yang keluar } \\
\text { di kran rumah anda selama } \\
24 \text { jam }\end{array}$ & 0 & 5 & 11 & 45 & 20 & 81 \\
\hline 5 & $\begin{array}{l}\text { Secara keseluruhan } \\
\text { bagaimana tingkat pelayanan } \\
\text { air bersih dari PDAM Tirta } \\
\text { Musi Palembang dalam } \\
\text { memenuhi kebutuhan sehari- } \\
\text { hari }\end{array}$ & 0 & 0 & 15 & 39 & 21 & 81 \\
\hline
\end{tabular}

Sumber : Analisis

Dari Tabel 18 dapat dilihat jawaban dari responden dan dianalisa sebagai berikut :

(1) Analisa Debit Air

Tabel 19. Kontinuitas Air - Debit Air

\begin{tabular}{|c|c|c|c|c|c|}
\hline \multicolumn{2}{|c|}{} & $\begin{array}{c}\text { Frequen } \\
\text { cy }\end{array}$ & Percent & $\begin{array}{c}\text { Valid } \\
\text { Percent }\end{array}$ & $\begin{array}{c}\text { Cumulati } \\
\text { ve } \\
\text { Percent }\end{array}$ \\
\hline \multirow{7}{*}{ Valid } & Sangat Tdk Puas & 1 & 1,23 & 1,23 & 1,23 \\
\cline { 2 - 6 } & Tidak Puas & 1 & 1,23 & 1,23 & 2,46 \\
\cline { 2 - 6 } & Cukup Puas & 19 & 23,46 & 23,46 & 25,92 \\
\cline { 2 - 6 } & Puas & 50 & 61,73 & 61,73 & 87,65 \\
\cline { 2 - 6 } & Sangat Puas & 10 & 12,35 & 12,35 & 100,0 \\
\cline { 2 - 6 } & Total & 81 & 100,0 & 100,0 & \\
\hline
\end{tabular}

Sumber : Pengolahan Data SPSS 
Berdasarkan hasil survei terhadap debit air yang dihasilkan pada kran air pelanggan diperoleh 1 responden $(1,23 \%)$ menyatakan Sangat tidak puas, 1 responden $(1,23 \%)$ menyatakan Tidak puas, 19 responden $(23,46 \%)$ menyatakan Agak puas, 50 responden $(61,73 \%)$ menyatakan Puas, 10 responden $(12,35 \%)$ menyatakan Sangat puas.

(2) Analisa Warna Air

Tabel 20. Kualitas Air - Warna Air

\begin{tabular}{|c|c|c|c|c|c|}
\hline \multicolumn{2}{|c|}{} & $\begin{array}{c}\text { Frequen } \\
\text { cy }\end{array}$ & Percent & $\begin{array}{c}\text { Valid } \\
\text { Percent }\end{array}$ & $\begin{array}{c}\text { Cumulati } \\
\text { ve Percent }\end{array}$ \\
\hline \multirow{4}{*}{ Valid } & Cukup Puas & 11 & 13,58 & 13,58 & 13,58 \\
\cline { 2 - 6 } & Puas & 43 & 53,09 & 53,09 & 66,67 \\
\cline { 2 - 6 } & Sangat Puas & 27 & 33,33 & 33,33 & 100,0 \\
\cline { 2 - 6 } & Total & 81 & 100,0 & 100,0 & \\
\hline
\end{tabular}

Sumber : Pengolahan Data SPSS

Berdasarkan hasil survei terhadap warna air yang dihasilkan pada kran air pelanggan diperoleh 11 responden $(13,58 \%)$ menyatakan Agak puas, 43 responden (53,09\%) menyatakan Puas, 27 responden $(33,33 \%)$ menyatakan Sangat Puas.

(3) Analisa Bau Air

Tabel 21. Kualitas Air - Bau Air

\begin{tabular}{|c|c|c|c|c|c|}
\hline \multicolumn{2}{|c|}{} & $\begin{array}{c}\text { Frequen } \\
\text { cy }\end{array}$ & Percent & $\begin{array}{c}\text { Valid } \\
\text { Percent }\end{array}$ & $\begin{array}{c}\text { Cumulati } \\
\text { ve Percent }\end{array}$ \\
\hline \multirow{4}{*}{ Valid } & Cukup Puas & 13 & 16,05 & 16,05 & 16,05 \\
\cline { 2 - 6 } & Puas & 47 & 58,02 & 58,02 & 58,02 \\
\cline { 2 - 6 } & Sangat Puas & 21 & 25,93 & 25,93 & 100,0 \\
\cline { 2 - 6 } & Total & 81 & 100,0 & 100,0 & \\
\hline
\end{tabular}

Sumber : Pengolahan Data SPSS

Berdasarkan hasil survei terhadap bau air yang dihasilkan pada kran air pelanggan diperoleh 13 responden $(16,05 \%)$ menyatakan agak puas, 47 responden $(58,02 \%)$ menyatakan puas, 21 responden $(25,93 \%)$ menyatakan sangat puas.

(4) Analisa Rasa Air

Tabel 22. Kualitas Air - Rasa Air

\begin{tabular}{|c|c|c|c|c|c|}
\hline \multicolumn{2}{|c|}{} & $\begin{array}{c}\text { Frequen } \\
\text { cy }\end{array}$ & Percent & $\begin{array}{c}\text { Valid } \\
\text { Percent }\end{array}$ & $\begin{array}{c}\text { Cumulati } \\
\text { ve Percent }\end{array}$ \\
\hline \multirow{4}{*}{ Valid } & Tidak Puas & 5 & 6,17 & 6,17 & 6,17 \\
\cline { 2 - 6 } & Cukup Puas & 11 & 13,58 & 13,58 & 19,75 \\
\cline { 2 - 6 } & Puas & 45 & 55,56 & 55,56 & 75,31 \\
\cline { 2 - 6 } & Sangat Puas & 20 & 24,69 & 24,69 & 100,0 \\
\cline { 2 - 6 } & Total & 81 & 100,0 & 100,0 & \\
\hline
\end{tabular}

Sumber : Pengolahan Data SPSS

Berdasarkan hasil survei terhadap rasa air yang dihasilkan pada kran air pelanggan diperoleh 5 responden $(6,17 \%)$ menyatakan tidak puas, 11 responden (13,58\%) menyatakan agak puas, 45 responden $(55,56 \%)$ menyatakan puas, 20 responden $(24,69 \%)$ menyatakan sangat puas.

(5) Analisa Kontinuitas Air

Tabel 23. Kontinuitas Air

\begin{tabular}{|c|c|c|c|c|c|}
\hline \multicolumn{2}{|c|}{} & $\begin{array}{c}\text { Frequen } \\
\text { cy }\end{array}$ & Percent & $\begin{array}{c}\text { Valid } \\
\text { Percent }\end{array}$ & $\begin{array}{c}\text { Cumulati } \\
\text { ve Percent }\end{array}$ \\
\hline \multirow{4}{*}{ Valid } & Tidak Puas & 6 & 7,41 & 7,41 & 7,41 \\
\cline { 2 - 6 } & Cukup Puas & 15 & 18,52 & 18,52 & 25,93 \\
\cline { 2 - 6 } & Puas & 39 & 48,15 & 48,15 & 74,08 \\
\cline { 2 - 6 } & Sangat Puas & 21 & 25,92 & 25,92 & 100,0 \\
\cline { 2 - 6 } & Total & 81 & 100,0 & 100,0 & \\
\hline
\end{tabular}

Sumber : Pengolahan Data SPSS

Berdasarkan hasil survei terhadap kontinuitas air yang dihasilkan pada kran air pelanggan diperoleh 6 responden $(7,41 \%)$ menyatakan tidak puas, 15 responden $(18,52 \%)$ menyatakan agak puas, 39 responden $(48,15 \%)$ menyatakan puas, 21 responden $(25,92 \%)$ menyatakan sangat puas.

Setelah didapat respoden rekapitulasi jawaban respoden, maka akan dicari tingkat kepuasan konsumen/respoden dengan menghitung tingkat kepuasan menggunakan SPSS.

Tabel 24. Descriptive Statistics

\begin{tabular}{|c|c|c|c|c|c|}
\hline & N & Min & Max & Mean & $\begin{array}{c}\text { Std. } \\
\text { Deviation }\end{array}$ \\
\hline Kkepuasan Pelanggan & 81 & 3,89 & 4,20 & 4,05 &, 7090 \\
\hline Valid N (listwise) & 81 & & & & \\
\hline
\end{tabular}

Sumber : Pengolahan Data SPSS

Dari hasil perhitungan disimpulkan bahwa hasil responden diketahui nilai kepuasan rata- rata adalah 4,05 .

Tabel 25. Skala Tingkat Kepuasan Pelanggan

\begin{tabular}{|c|c|c|}
\hline NO & Keterangan & $\begin{array}{c}\text { Nilai Skala } \\
\text { Peringkat }\end{array}$ \\
\hline 1. & Sangat Tidak Puas & $1 \leq \mathrm{X} \leq 1,8$ \\
\hline 2. & Tidak Puas & $1,9 \leq \mathrm{X} \leq 2,6$ \\
\hline 3. & Cukup Puas & $2,7 \leq \mathrm{X} \leq 3,4$ \\
\hline 4. & Puas & $3,5 \leq \mathrm{X} \leq 4,2$ \\
\hline 5. & Sangat Puas & $4,3 \leq \mathrm{X} \leq 5$ \\
\hline
\end{tabular}

Sumber : Statistik (J. Supranto, 2009)

Dari tabel 25, untuk skala tingkat kepuasan pelanggan maka dengan nilai 4,05 pelanggan PDAM merasa Puas dengan air yang dikonsumsi dari PDAM Tirta Musi Unit 3 Ilir Palembang DMA Taman Kenten. 


\section{KESIMPULAN}

Berdasarkan hasil analisa yang dilakukan oleh peneliti pada bab sebelumnya, maka dapat diambil kesimpulan sebagai berikut :

1. Indikator kehilangan fisik (ILI) pada setelah pemasangan DMA Unit 3 Ilir PDAM Tirta Musi Palembang terbesar sebesar 10.98. Nilai tersebut termasuk dalam kategori kelas C, dimana indikatornya adalah pencatatan kebocoran yang buruk; hanya dapat ditoleransi bila airnya berlimpah dan murah; meskipun begitu, harus tetap dianalisis tingkat dan penyebab kebocoran dan intensifkan upaya penurunan kebocoran.

2. Skala tingkat kepuasan pelanggan terhadap pelayanan setelah pemasangan DMA unit 3 Ilir pada DMA Taman Kenten senilai 4.05 , artinya pelanggan PDAM merasa puas dengan air yang dikonsumsi dari PDAM Tirta Musi Unit 3 Ilir Palembang.

\section{DAFTAR PUSTAKA}

Departemen Pekerjaan Umum Direktorat Jendral Cipta Karya. 2005. Petunjuk Teknis Pelaksanaan Prasarana Air Minum Sederhana

Departemen Pekerjaan Umum. 2009. Pedoman Operasi dan Pemeliharaan Unit Distribusi, Jakarta.

Dighade.RR, at all. 2015. Non Revenue Water Reduction Strategy in Urban Water Supply System in India. International Journal of Research in Engineering and Applied Sciences, Vol. 3, PP. 17-24, ISSN : 22499210.

Marsillina, Eptaria. 2012. Studi Kebocoran Pada Jalur Distribusi PDAM Cempaka Dalam Kelurahan 26 Ilir Palembang Dengan Program DMA (District Matered Area). Palembang. Politeknik Negeri Sriwijaya.

Mathur. YP, Vijay Arvind, 2013. Non Revenue Water Reduction - A Tool For Achiving $24 x 7$ Water Supply, IOSR Journal of Mechanical and Civil Engineering Vol. 7 PP 25-28, India.

Nugraha, Winardi Dwi, 2010. Studi Kehilangan Air Akibat Kebocoran Pipa Pada Jalur Distribusi PDAM Kota Magelang, Magelang : Universitas Diponegoro.
Supranto, J. 2009. Statistik : Teori dan Aplikasi Jilid II, Erlangga, Jakarta.

Suwardi. 2013. Analisa Kinerja Sistem Distribusi Air Bersih Pada Komplek Perumahan Karyawan PT. Medco E\&P Indonesia Rimau Asset. Palembang : Universitas Tridinanti Palembang.

Training of Trainer (TOT). 2008. Departemen Pekerjaan Umum Badan Pendukung Pengembangan Sistem Penyediaan Air Minum (Pendamping Non Revenue Water). Palembang : PT. Gafa Multi Consultant.

Penang Water Services Academy. 2010. Water Distribution Technology, Malaysia

Pickard. Brian, at all, 2008. Reducing Non Revenue Water : A Myriad of Challenges. Florida Water Resources Journal, Florida.

Putra, Cokorda Gde Dharma. 2011. Analsis Kepuasan Pelanggan Pada Perusahaan Daerah Air MInum (PDAM) di Kabupaten Jembarana. Denpasar : Universitas Udayana Denpasar.

Putri, Mareta. 2014. Analisa NRW Sistem Jaringan DistribusiAir Bersih PDAM Tirta Musi Palembang Dengan Distric Meter Area (DMA) Wilayah Naskah. Palembang : Universitas Tridinanti

Setiawaty, Elys, 2013. Analisa Kehilangan Air Pada Instalasi Pengolahan Air (IPA) Perusahaan Daerah Air Minum (PDAM) Tirta Musi Rambutan Palembang, Palembang : Universitas Tridinanti 